\title{
LOST PROFITS AS CONTRACT DAMAGES: PROBLEMS OF PROOF AND LIMITATIONS ON RECOVERY
}

\begin{abstract}
"[A]lthough an excellent attempt was made in Hadley $v$. Baxendale to lay down a rule on the subject, it will be found that the rule is not capable of meeting all cases; and when the matter comes to be further considered, it will probably turn out that there is no such thing as a rule, as to the legal measure of damages applicable in all cases."

-WILDE, B. $\dagger$

A BUSINESSMAN enters into a commercial contract expecting to give and receive full performance. ${ }^{1}$ When a breach of contract destroys the possibility of full performance as promised, the law substitutes damages for the businessman's lost expectation: $:^{2}$ the breaching party must put the injured party in the same financial position he would have enjoyed had the contract been performed. ${ }^{3}$ Most often, the injured party can minimize his injury by making a substitute purchase or sale. When this is possible, the injured party is fully compensated by receiving the difference between the original contract price and the prevailing market price at which the substitute contract could have been made. ${ }^{4}$
\end{abstract}

†Gee v. The Lancashire \& Yorkshire Ry., 6 H. \& N. *211, *221, 158 Eng. Rep. 87, 91 (Ex. 1860).

1. "[A] person contemplates the performance and not the breach of his contract; he does not enter into a kind of second contract to pay damages. ..." Hydraulic Engineering Co. v. McHaffie, 4 Q.B.D. 670 (1878). See also Globe Refining Co. v. Landa Cotton Oil Co., 190 U.S. 540, 543 (1903) ; 5 CoRBIn, Contracts $\$ \$ 1008-09$ (1951) (hereinafter cited as CoRBIN) and authorities there cited.

2. The fundamental purpose of contract damages is compensation of the injured party. Miller v. Robertson, 266 U.S. 243 (1924) ; American Pulp \& Paper Co. v. Denenberg, 132 F. Supp. 802 (E.D. Pa. 1955) ; Ficara v. Belleau, 331 Mass. 80 , 117 N.E.2d 287 (1954); Donald W. Lyle, Inc. v. Heidner \& Co., 45 Wash. $2 d$ S06, 278 P.2d 650 (1950).

3. Orebaugh v. Antonious, 190 Va. 829, 58 S.E.2d 873 (1950) ; Restatentent, ConTRACTs $\$ 329$, comment $a$ (1932); cases cited note 2 supra. See also Friedman Iron \& Supply Co. v. J. B. Beaird \& Co., 222 La. 627, 63 So. 2d 144 (1952) (civil law rule).

4. Se'e, e.g., Masterson v. Mayor of Brooklyn, 7 Hill 61 (N.Y. Sup. Ct. 1845) ; Olcese v. Davis, 124 Cal. App. 2d 58, 268 P.2d 175 (1954); 5 CoRBIN $\$ \$ 1039$, 1100-01. If plaintiff does in fact make a reasonably diligent cover contract, the price of that contract is prima facie evidence of the market price. Miller v. Robertson, 266 U.S. 243 (1924) ; King v. D. E. Ryan Co., 179 Minn. 385, 229 N.W. 348 (1930). See also cases collected in Growers' Exchange v. John A. Eck Co., 66 Utah 340, 242 Pac. 391 (1925) ; Uniform Sales Acr ANN. $\S 64$ n.170, $\S 67 \mathrm{n} .193$ (1950). But damages will not be awarded for losses which could have been prevented by making a substitute, or "cover" contract; such losses are "avoidable consequences" of the breach. See cases cited note 47 infra and accompanying text.

If, of course, a sale has been consummated, the seller has a damage action for the full price. Under the Uniform Sales Act the sale is consummated at the time intended by the parties for property in the goods to pass to the buyer. UNIForM SALES AcT $\$ \$ 17-20$, 63(1). The sale may also be deemed consummated if the buyer refuses to make a payment due the seller irrespective of delivery and title passage, $i d$. $\$ 63(2)$, or if after breach the goods can not readily be resold at a reasonable price, $i d . \S 63(3)$. 
Frequently, however, a substitute contract cannot be made, and the injured party can recover his lost expectation only by receiving the profits he would have earned had there been no breach. He must then establish his damages directly by proving what his income and his costs would have been but for the breach.

The same over-all policy of awarding compensation exists in both cases. But while courts apply the market formula consistently, 5 they have treated claims for lost profits erratically: they frequently award less than full compensation or deny recovery altogether, ${ }^{6}$ holding that the profit allegedly lost was too "contingent, speculative or remote." This Comment will attempt to survey the galaxy of problems presented by claims for lost profits and to offer new methods of analysis which appear more consonant with commercial needs and practice.

\section{Lost Profits in Context}

Claims for lost profits arise in two types of situations where market conditions after breach do not permit the injured party to make a substitute contract. In the first, plaintiff-the injured party-sells to a market in which supply exceeds demand; he may be either a middleman ${ }^{8}$ who can obtain more goods from his suppliers than he is able to resell, or a producer or manufacturer whose capacity exceeds the demand for his product. ${ }^{2}$ Defendant is a buyer who

5. The market formula is used despite a showing that its application overcompensates the plaintiff for actual losses. UnIronar Sales Acr $\$ \$ 64(3), 67(3)$. See, e.g., Brightwater Paper Co. v. Monadnock Paper Mills, 161 F.2d 869 (1st Cir. 1947) ; Werfel v. United States, 83 F. Supp. 507, 509 (S.D.N.Y. 1948) (dictum). Contra, Donald W. Lyle, Inc. v. Heidner \& Co., 45 Wash. 2d S06, S17, 278 P.2d 650, 656-57 (1954) (dictum). Presumably this is because courts consider use of the market formula less complex than measuring lost profits directly. See Norwood Lumber Co. v. McKean, 153 F.2d 753, 755 (3d Cir. 1946) (dictum). But cf., e.g., Friedman Iron \& Supply Co. v. J. B. Beaird Co., 222 La. 627, 63 So. $2 \mathrm{~d} 144$ (1952) (market formula applied correctly only upon second rehearing).

6. In one case in which plaintiff's loss could be determined only by direct measurement of prospective income and costs the court refused to award damages measured by the market (OPA ceiling)-contract differential, even though this measure undoubtedly would have been no more than plaintiff's actual loss. Buyer v. Mercury Technical Cloth \& Felt Corp., 301 N.Y.74, 92 N.E.2d 896 (1950).

7. See, e.g., Paul v. Camden Motor Co., 221 Ark. 702, 255 S.W.2d 418 (1953) ; Brumby Metals, Inc. v. Spalding Foundry Co., 89 Ga. App. 464, 79 S.E.2d 568 (1953); Western Show Co. v. Mix, 30 Pa. 215, 162 Atl. 667 (1932).

8 . The term "middleman" will hereinafter be used to refer to one who buys and resells goods or services without materially changing their form or substance. See notes $45-110$ infra and accompanying text.

9. The term "manufacturer" will hereinafter be used to denote one who produces goods or services; the term includes farmers and construction contractors as well as industrial manufacturers. See notes 45-75, 111-34 infra and accompanying text. When a manufacturer is producing goods specially ordered by defendant, it may be extremely difficult to find another buyer for the special goods. Manufacturer's supply then exceeds his demand; he therefore can recover the direct profit he would have made by selling to defendant. Hinckley v. Pittsburgh Bessemer Steel Co., 121 U.S. 264 (1887); Gardner v. Deeds \& Hirsig, 116 Tenn. 128 (1905) ; Note, 99 U. PA. L. Rev. 229, 234-35 (1950). But he must avoid 
breached a contract to buy from the plaintiff. ${ }^{10}$ In a market in which supply exceeds demand, plaintiff's profits cannot be recaptured by a substitute sale, since plaintiff cannot find buyers he would not have been able to supply in any event. Therefore an award of damages based on the difference between contract price and the market price in the buyer's market will not be sufficient to compensate plaintiff for the added profit he could have made by selling to defendant." Plaintiff claims a "loss of bargain" measured by the contract price minus the cost of supplying the goods to the buyer. ${ }^{12}$

In the second type of situation, plaintiff is a buyer of goods which he planned to use in a transaction collateral to his contract with the defendantsupplier. Plaintiff may have planned to resell the goods directly, as a middleman, ${ }^{13}$ or, as a manufacturer, to use them as raw materials or capital goods. ${ }^{14}$ If defendant breached his contract by failing to deliver, delivering late or delivering unusable goods, and if plaintiff were unable to obtain substitute goods from other sellers, ${ }^{15}$ defendant's breach would delay plaintiff's collateral transaction, frustrate it completely or considerably increase its costs. Either effect would correspondingly diminish profits plaintiff could have made on the collateral undertaking, ${ }^{16}$ or cause him to lose the accounts of customers he was unable to serve. ${ }^{17}$

aggravating his damages by stopping production of goods which would be unsalable once he has notice of the breach. Ibid; UNIForM SALES Act $\$ 64(4)$. See UNIFORM Conmererctal Code \$ 2-704.

10. It is assumed that defendant breached before the sale was "consummated," and therefore is not liable for the full contract price. See Weiss v. Sheet Metal Fabricators, 206 Md. 195, 110 A.2d 671 (1955); Allen, Heaton \& McDonald, Inc. v. Castle Farm Amusement Co., 151 Ohio St. 522, 86 N.E.2d 782 (1949); Uniforar Sales ACT $\$ 63(1)$; note 4 supra.

11. Barron G. Collier, Inc. v. Kindy, 146 Minn. 279, 178 N.W. 584 (1920); Locks v. Wade, 36 N.J. Super. 128, 114 A.2d 875 (App. Div. 1955) ; 1 Bongright, ValuatToN of PROPERTY 304-05 (1937).

12. Hinckley v. Pittsburgh Bessemer Steel Co., 121 U.S. 264 (1887); Philadelphia, W. \& B.R.R. v. Howard, 54 U.S. (13 How.) 307 (1851) ; J. A. Laporte Corp. v. Pennsylvania Dixie Cement Corp., 164 Md. 642, 165 At1. 195 (1933). Cf. 1 Bonbright, ValunTION OF PROPERTY 304-05 (1937).

13. See notes 76-110 infra and accompanying text.

14. See notes 111-34 infra and accompanying text.

15. Goods must be of comparable quality to the contract goods to qualify as substitutes. Davis v. Koppers Co., 335 Mich. 9, 55 N.W.2d 152 (1952) ; Rich v. Bongiovanni, 4 N.J. Super. 243, 66 A.2d 888 (App. Div. 1949) ; Hill's, Inc. v. William B. Kessler, Inc., 41 Wash. 2d 42, 246 P.2d 1099 (1952). Comparable goods are not substitutes if they are drawn from a limited supply that would otherwise have been available for additional profitable transactions. The plaintiff-buyer is therefore in the same situation as the plaintiffseller selling to a market where demand is less than supply, see notes 8-12 supra and accompanying text. He cannot be compensated by the market minus contract price rule. American Pulp \& Paper Co. v. Denenberg, 132 F. Supp. 802 (E.D. Pa. 1955).

16. Panno v. Russo, 82 Cal. App. 2d 408, 186 P.2d 452 (1947) (prevented resale); Evergreen Amusement Corp. v. Milstead, 206 Md. 610, 112 A.2d 901 (1955) (delayed theatre opening) ; Royal Pioneer Paper Box Mfg. Co. v. Louis De Jonge \& Co., 115 A.2d 837 (Pa. Super. 1955) (increased costs).

17. W. L. Mead, Inc. v. International Brotherhood of Teamsters, 129 F. Supp. 313 
The considerations which have led the courts to compensate businessmen for losses measurable by the market rule of contract damages also support compensation for lost profits which must be measured directly. Businessmen ordinarily rely on executory contracts not only by incurring out-of-pocket "reliance" expenses but also by avoiding duplicate contracts of supply, ${ }^{18}$ foregoing subsequent opportunities to resell, ${ }^{19}$ and gearing their business to the performance they expect to receive. ${ }^{20}$ Such reliance increases the speed and reduces the costs of production and distribution. Furthermore, the commercial world places a present value on a promise of future performance. This credit value permits businessmen to finance their undertakings by borrowing against executory contracts. ${ }^{21} \mathrm{By}$ awarding compensatory damages when a contract is breached, the courts help to preserve the credit structure; for a broken promise of future performance they substitute a money judgment of equal value. The courts also encourage businessmen to rely on contracts with confidence by reimbursing injured parties for expenses they incurred by relying on full performance. ${ }^{22}$ But these goals can be only partially implemented if promisees are not also awarded the profits they were unable to realize because of a breach. For the promisee who relies on a contract as well as the lender who gives credit on it must determine the value of the contract to the promisee; and this value necessarily reflects profits the promisee would have made, had the contract been kept.

There are other considerations, however, seldom apposite when damages can be measured by the general market formula, which demand special treatment for lost profits claims. The first consideration, applicable only in collateral profits situations, is that the profit anticipated by plaintiff may be so large, so unexpected by defendant and so disproportionate to the consideration defendant would have received from performance, that full compensation would be commercially undesirable. It is one thing to prevent defendant from securing a better position by breach than he could have gained by performance;

(D. Mass. 1955), aff'd, 230 F.2d 576 (1st Cir. 1956). But cf. Globe Refining Co. v. Landa Cotton Oil Co., 190 U.S. 540 (1903).

18. See Ross v. Frank W. Dunne Co., 119 Cal. App. 2d 690, 260 P.2d 104 (1953) (plaintiff-dealer elected to switch from competitor's line to defendant's line); Strietelmeier v. Angelo, 113 N.E.2d 771 (Ohio C.P. 1951).

19. See, e.g., Nelson Equipment Co. v. Harner, 191 Ore. 359, 230 P.2d 188 (1951) (dealer); Jessup \& Moore Paper Co. v. Bryant Paper Co., 297 Pa. 483, 147 At1. 519 (1929) (manufacturer).

20. See, e.g., Consolidated Flour Mills Co. v. File Bros. Wholesale Co., 110 F.2d 926 (10th Cir. 1940) (seller prepares to manufacture); Clyde Coal Co. v. Pittsburgh \& L.E. R.R., $226 \mathrm{~Pa}$ 391, 75 Atl. 596 (1910) (buyer makes forward contracts).

21. Honsold, Sales and Sales Financing 588 (1954); see Royal Indemnity Co. v. United States, 117 Ct. Cl. 736, 741, 93 F. Supp. 891, 893 (1950).

22. Promoting reliance and preserving credit value are the court's primary purposes in awarding compensatory damages equal to the benefit expected from full performance. Fuller \& Perdue, The Reliance Interest in Contract Damages, 46 YALE L.J. 52, 57-66 (1936). 
it is quite another to place him in a much worse position. Although some harm to defendant's interests may be warranted to deter breach, ${ }^{23}$ there are overriding considerations which demand that recovery be limited. ${ }^{24}$ Aside from the possibility of exceeding the defendant's financial limitations, disproportionate damages may induce defendant and other businessmen in similar occupations to shun bilateral contracts entirely or to insure against future losses by insisting on liquidated damages that fall short of full compensation, even when the loss would not be disproportionate. A distant but real effect of excessive verdicts would thus be not only to prevent businessmen from relying on promises of future performance, but also to discourage prospective creditors from giving value to many commercial transactions.

A second consideration, applicable to all lost profits claims, is that measuring unrealized profits entails extensive problems of proof. Plaintiff is entitled to the total amount he would have received minus those costs of performance that he did not actually incur. ${ }^{25}$ These costs must often be proved by subtracting costs actually incurred before breach from the estimated total cost of performance. ${ }^{26}$ An alternative formula allows plaintiff the net income (gross income minus total costs) he would have earned plus the costs he had already incurred. ${ }^{27}$ Under both methods, any present value plaintiff retains from expenditures made before breach must be subtracted from the amount recovered. ${ }^{28}$ Thus, either formula requires proof of income and costs. If plaintiff

23. While deterring breach is not the primary goal of damage law, see note 2 supra, it is an important consideration. See 5 CoRBIn $\$ \S 997,1006$; Fuller \& Perdue, stipra note 22, at 61-62. Punishing breach, however, is not an aim of contract damage law. See Ficara v. Belleau, 331 Mass. 80, 117 N.E.2d 287 (1954); Restatenrent, Contracts $\$ 342$ (1932).

24. See Flug v. Craft Mfg. Co., 3 Ill. App. 2d 56, 120 N.E.2d 666 (1954); Thurner Heat Treating Co. v. Memco, Inc., 252 Wis. 16, 30 N.W.2d 228 (1947) ; 5 ConBri $\$ \S 1016-$ 18 .

25. Hinckley v. Pittsburgh Bessemer Steel Co., 121 U.S. 264 (1887) (sellers' loss); Allen, Heaton \& McDonald, Inc. v. Castle Farm Amusement Co., 151 Ohio St. 522, 86 N.E.2d 782 (1949) (same) ; Kelly v. Valley Constr. Co., 43 Wash. 2d 679, 262 P.2d 970 (1953) (same) ; Transit Advertisers v. New York, N.H. \& H.R.R., 194 F.2d 907 (2d. Cir.), cert. denied, 344 U.S. 817 (1952), aff'd, 203 F.2d 852 (2d Cir. 1953) (buyers' loss); Bale v. Brudevig, 77 N.D. 494, 43 N.W.2d 753 (1950) (same). Plaintiff can also recover any expenses reasonably incurred in mitigating his losses. Royal Pioneer Paper Box Mig. Co. v. De Jonge \& Co., 115 A.2d 837 (Pa. Super. 1955) ; Columbia Produce Co. v. Tiskowitz, 134 Pa. Super. 145, 3 A.2d 990 (1939).

26. See, e.g., Tuttle v. Bootes Hatcheries \& Packing Co., 112 F. Supp. 705 (D. Minn. 1953); Haddad v. Western Contracting Co., 76 F. Supp. 987 (N.D. W. Va. 1948) ; SheldonSeatz, Inc. v. Coles, 319 Mich. 401,29 N.W.2d 832 (1947).

27. Hinckley v. Pittsburgh Bessemer Steel Co., 121 U.S. 264 (1887) ; United States v. Behan, 110 U.S. 338 (1884); Wright v. Ickenroth, 215 S.W.2d 43 (Mo. Ct. App. 1948). Contra Atlanta Gas Light Co. v. Newman, 88 Ga. App. 252, 76 S.E.2d 536 (1953) (court reasoned that net profit and expense incurred in earning profit would be double recovery) (semble).

28. United States v. Behan, 110 U.S. 338 (1884) ; Harrell v. Davis, 210 Ark. 939, 198 S.W.2d 180 (1946) ; Wright v. Ickenroth, 215 S.W.2d 43 (Mo. Ct. App. 1948). Under a third formula plaintiff would receive the same proportion of the contract price as the costs 
had contracted to sell to defendant, his estimated income is equal to the contract price, but if plaintiff had contracted to buy from defendant and claims a loss of collateral profits, income may depend on consumer preferences and demand for the goods plaintiff planned to produce or resell. Proof of costs is equally difficult; in addition to the cost of the goods involved, the expenses which plaintiff incurred or which he saved by not having to complete performance include such variables as delivery, merchandising and advertising expenses, and the joint costs of operating a factory or large construction enterprise.

The courts have developed three special rules to limit the recovery of unrealized profits. The first rule requires plaintiff to show that defendant's breach was the cause of the loss. ${ }^{29}$ This, of course, is always true, but in this area, courts have given restrictive and imprecise definitions to the term "cause" in order to avoid large verdict and proof problems. ${ }^{30}$ The second rule is the "foreseeability" theory of Hadley $v$. Baxendale:31 compensation cannot be awarded for a loss unless, at the time the contract was made, defendant could have reasonably foreseen, or had notice, that loss of profits would be a probable consequence of a breach. ${ }^{32}$ The third rule, developed in earlier

incurred bear to the estimated total cost, plus the same proportion of the total net profit expected that the unincurred costs bear to total costs. WRIGHT, Rensedies 363-65 (1955). All three formulas yield identical results, and may be used interchangeably depending upon which variables may be most easily ascertained.

29. Washington Sand \& Gravel Co. v. Bramm \& Stuart Co., 162 F.2d 826 (3d Cir. 1947); Heflebower v. Sand, 71 F. Supp. 607 (D. Minn. 1947); Addison Miller, Inc. v. United States, 70 F. Supp. 893 (Ct. Cl.), cert. denied, 332 U.S. 836 (1947).

30. See, c.g., Erumby Metals, Inc. v. Spalding Foundry Co., 89 Ga. App. 464, 79 S.E.2d 586 (1953) (loss was "foreseeable" but too "remote") ; Richardson v. Crone, 127 Mont. 200, 258 P.2d 970 (1953) ("intervening cause") ; Foss v. The Pacific Tel. \& Tel. Co., 26 Wash. 2d 92, 173 P.2d 144 (1946) (breach must be "proximate" cause). See also note 34 infra.

In practice, it is difficult enough to determine whether given losses are in fact caused by the breach. But this difficulty should not be complicated by reading concepts of foreseeability or certainty into cause. It will be hereinafter assumed in this Comment that losses claimed by plaintiff have been caused in fact by defendant's breach.

31. 9 Ex. 341, 156 Eng. Rep. 145 (1854).

32. See, e.g., Huler v. Nasser, 322 Mich. 1, 33 N.W.2d 637 (1948) ; Pope v. Ferguson, 82 N.J.L. 566, 83 Atl. 353 (1912) ; McCoRurck, Dasrages $\$ 138$ (1935). The rule, as stated in Hadley v. Baxendale, requires that the loss be either the natural consequence of the breach or within what the parties could reasonably have contemplated as a probable consequence of breach. But cf. Eastern Paper \& Box Co. v. Herz Mfg. Co., 323 Mass. 138, 145, 80 N.E.2d 484, $4 \$ 9$ (1948) (misstating the rule to require both elements) (dictum). For a discussion of the semantic relationship between the two parts of the rule see Gow, A Comment on the Rule in Hadley v. Baxendale, 27 Austr. L.J. 666 (1954).

The foreseeability rule is not applied when damages can be awarded by the marketcontract price differential. United States v. Burton Coal Co., 273 U.S. 337 (1927) (seller's loss as measured by market formula deemed natural consequence of breach, although market had dropped sixty-eight per cent) ; Uniforar SALES ACT $\$$ 64(3), 67(3) (market formula applicable whenever loss not proven greater); Brightwater Paper Co. v. Monadnock 
American cases, ${ }^{33}$ is that lost profits cannot be recovered as damages unless they can be proved with "certainty." "34 In estimating his losses, plaintiff's evidence must postulate events which did not in fact occur; this conjectural element present in all lost profits cases could always be fatal to plaintiff were the certainty rule strictly applied.

The rules are not mutually exclusive; like all semantic rules, their referrents are not clearly defined, and overlap. ${ }^{35}$ Although the foreseeability rule is directed primarily toward the problem of excessive damages and the certainty rule toward the problem of proof, the distinction is often blurred and either rule can be related to both problems. ${ }^{36}$ The cause rule as well has been intermittently linked with both foreseeability and certainty. ${ }^{37}$ Each rule can be

Paper Mills, 161 F.2d 869 (1st Cir. 1947) (same); see 1 Bonbright, Valdation of PROPERTY 291 n.50 (1937) (author found only one case contra).

33. See The Schooner Lively, 1 Gall. 315 (C.C. Mass. 1812) ; Masterson v. Mayor of Brooklyn, 7 Hill 61 (N.Y. Sup. Ct. 1845); McCorarck, DaMrages $\$ 25$ (1935).

34. The certainty rule is sometimes said to apply only to the question of cause, not to the amount of damages. See, e.g., Kelly v. Valley Constr. Co., 43 Wash. 2d 679, 262 P.2d 970 (1953). In applying the rule, however, courts frequently require certainty as to the amount, after cause has been established. See, e.g., Griffin v. Colver, 16 N.Y. 489 (1858), a leading case whose language has often been used for the proposition that certainty applies only to cause, not the amount, of damages. The court, although it excluded evidence for lack of "certainty," could not have been doubtful as to cause: the court awarded plaintiff damages for the same breach, although based on an alternate theory of damages. See also MacKenzie Laboratories v. Lawrence, 80 F. Supp. 710 (D. Md. 1948) ; Kurtz v. Oremland, 33 N.J. Super. 443, 111 A.2d 100 (Ch. 1954). See McCormick, DaMrages $\$ 27$ (1935).

35. If the loss was foreseeable by the parties, the "cause" rule is satisfied unless there is a supervening force. See 5 Corbin $\$ 1006$. Certainty and foreseeability also overlap, since a contingency that makes plaintiff's loss uncertain will often make it difficult for defendant to have foreseen the loss. See, e.g., E. I. du Pont de Nemours \& Co. v. Universal Moulded Products Corp., 191 Va. 525, 62 S.E.2d 233 (1950). And it is often difficult to determine whether lost profits have been denied because of uncertainty as to cause or as to amount. See Shealy's, Inc. v. Southern Bell Tel. \& Tel. Co., 126 F. Supp. 382 (E.D. S.C. 1954); Mabry v. Midland Valley Lumber Co., 217 La. 877, 47 So. $2 \mathrm{~d} 673$ (1950); California Eastern Airways, Inc. v. Alaska Airlines, Inc., 38 Wash. 2d 378, 229 P.2d 540 (1951).

36. The opinions in the cases formulating the certainty rule were concerned with the difficult and time-consuming problems of proving lost profits. See particularly The Schooner Lively, 1 Gall. 315, 325 (C.C. Mass. 1912) ; Masterson v. Mayor of Brooklyn, 7 Hill 61, 67-69, 71-73 (N.Y. Sup. Ct. 1845). But the large verdict problem also finds expression in these opinions. See particularly $i d$. at 73. And in Hadley v. Baxendale, 9 Ex. 341, 156 Eng. Rep. 145 (1854), which introduced the foreseeability rule into the common law, defendant's argument for the foreseeability rule was supported primarily by a quote from SEDGWICK, Damages 78 (1847), repeating the proof problem language from $T h e$ Schooner Lively opinion, supra. See Hadley v. Baxendale, supra at 350-51, 156 Eng. Rep. at 149 . The large verdict problem also influenced the court, however. See id. at 355,156 Eng. Rep. at 151; notes 135-38 infra and accompanying text. See Washington, Damages in Contract at Common Law, 48 L.Q. Rev. 90, 97-108 (1932).

37. See notes 30,35 supra and accompanying text; Green, Rationale of Proximate Cause 44-45 (1927) ; Note, 46 Harv. L. Rev. 696, 697 (1933). See also 5 Corbin $\$ \$ 997$, 1006. 
invoked not only to deny recovery after trial on the merits, ${ }^{38}$ but also to exclude evidence offered to prove the profits lost. ${ }^{39}$

Both as rules of evidence and as guides for analysis, the three rules have provided unsatisfactory criteria for resolving the proof and damages problems peculiar to lost profits cases. The highly restrictive law of evidence under which these rules developed has become obsolete; statutory reform has simplified many proof problems by liberalizing the rules of competence ${ }^{40}$ and admissibility. ${ }^{41}$ As business practices become institutionalized, businessmen acquire greater knowledge of the natural and probable consequences of their

38. Western Union Tel. Co. v. R. J. Jones \& Sons, 211 F.2d 479 (5th Cir. 1954) (certainty) ; MacKenzie Laboratories, Inc. v. Lawrence, 80 F. Supp. 710 (D. Md. 1948) (same) ; Schoenberg v. Forrest, 253 S.W.2d 331 (Tex. Civ. App. 1952) (same); Oxford Sporting Goods Mig. Co. v. Gillman, 97 Ohio App. 269, 125 N.E.2d 214 (1953) (foreseeability); Flug v. Craft Mfg. Co., 3 IIl. App. 2d 56, 120 N.E.2d 666 (1954) (same) ; Pope v. Ferguson, 82 N.J.L. 566, 83 At1. 353 (1912) (same).

39. Evergreen Amusement Corp. v. Milstead, 206 Md. 610, 112 A.2d 901 (1955) (certainty) ; Weiss v. Revenue Bldg. \& Loan Ass'n, 116 N.J.L. 208, 182 Atl. 891 (1936) (same); Western Show Co. v. Mix, $308 \mathrm{~Pa} .215,162$ Atl. 667 (1932) (same); Hadley v. Baxendale, 9 Ex. 341, 156 Eng. Rep. 145 (1845) (foreseeability) ; Clyde Coal Co. v. Pittsburgh \& L.E.R.R., 226 Pa. 391, 75 Atl. 596 (1910) (same) ; Foss v. The Pacific Tel. \& Tel. Co., 26 Wash.2d 92, 173 P.2d 144 (1946) (same).

40. Parties to a civil suit were incompetent as witnesses in England until 1851. Lord Brougham's Act, 1851, 14 \& 15 VICr. c. 99, $\$ 2 ; 2$ WIGAroRe, EvidENCE $\$ \$ 575,577$ (3d ed. 1940). Plaintiff was therefore unable to testify in his own behalf as to his plans for realizing a profit. Moreover, since a party was not obliged to testify against himself, see, e.g., MCCokMick, Evidence $\$ 65$ (1954), defendant could not call plaintiff to correct any cxaggeration introduced by plaintiff's witnesses. But see Norden v. Williamson, 1 Taunt. 378, 127 Eng. Rep. 880 (C.P. 1808) (plaintiff consented to testify for defendant).

All interested persons were similarly incompetent until 1843. Lord Denman's Act, 1843, $6 \& 7$ VICT. c. $85 ; 2$ WigMone, EvIDENCE $\$ \$ 575,576$ (3d ed. 1940). Thus a broker might be unable to testify as to collateral contracts negotiated by him unless he was acting in the usual course of his business with plaintiff. 1 GREENLEAF, EvideNCE $\$ \S 416-17$ (1842); 1 Mforgan, Basic Problems of Endence 83-84 (1954).

In the United States the same restrictions prevailed until removed by statutes following the English reform. 2 Wigarore, Evidence $\$ \S 488,576-77$ (3d ed. 1940).

41. At common law business records were generally inadmissible unless: (1) the entrant testified that each entry was a correct record of fact known to him when he made the entry, and if the entrant derived his knowledge from a report, each person making or transmitting the report verified his part in the reporting process, or (2) the entry was made by a clerk who died before trial or by a party who kept no clerk. For complete analysis of the common law rules see 5 Wrgmore, Evmence $\$ \$ 1517-61$ (3d ed. 1940). Thus the proof of lost profits could be an interminable process.

The Uniforar Business Reconds as Evidence ACt and the Commonwealth Fund's Model Business Records Act have greatly liberalized admissibility of business records. Sce, c.g., Morgan, Evidence: Some Proposals for Reforms 51-63 (1927); Norville, The Uniform Business Records as Evidcnce Act, 27 ORE. L. REv. 188 (1948). These statutes have been widely adopted. See statutes collected in MCCorarick, EvroEnCE $\$ 289$ nn.7 \& 8 (1954).

Until recently, the courts also excluded market reports as hearsay; now courts generally admit published reports when they appear to be reliable. 6 WIGMORE, EvIDENCE $\$ 1704$ 
acts. Courts rigidly adhering to stare decisis have denied claims that presented no real problems. ${ }^{42}$ Other courts, probably aware of a need for fresh analysis, have broken from precedent; but, not stating the reasons for their departure, ${ }^{43}$ they seldom establish guideposts for future litigation. Thus, although the law seems to be moving towards more widespread allowance of lost profits as damages, its course cannot be charted with any certainty or predictability.

\section{Sellers' Claints for Direct Profits}

A seller suing a breaching buyer must be able to prove two conclusions of fact to recover unrealized direct profits. He must show first that if the contract had been performed he would have delivered goods to the buyer at a cost less than the price he was to receive; the price-cost differential represents the profit lost. ${ }^{44}$ The price can usually be established solely by the terms of the contract. ${ }^{45}$ Costs, however, may be more difficult to prove since they comprise, at least in part, expenses which have never been incurred.40 Secondly, the seller must be able to show that his supply of goods or capacity to produce goods exceeded his demand after breach. Since excess demand would have enabled the seller to mitigate losses by procuring a substitute contract, any loss greater than the difference between the original contract price and the price of a substitute contract would be an "avoidable consequence" of the breach. ${ }^{47}$

The courts have given favored treatment to sellers' claims for loss of direct profits. They have universally held that a buyer bargaining with a businessman could necessarily foresee that the prospect of selling above cost was the

(3d ed. 1940) ; Comment, 45 MicH. L. Rev. 748 (1947). See, e.g., Webber v. Umback, 125 Kan. 117, 263 Pac. 786 (1928) ; Friedman Iron \& Supply Co. v. J. B. Beaird Co., 222 La. 627,63 So. $2 \mathrm{~d} 144$ (1952). See also notes 146-50 infra and accompanying text.

42. See, e.g., Oxford Sporting Goods Mfg. Co. v. Gillman, 97 Ohio App. 269, 125 N.E.2d 214 (1953) ; Clyde Coal Co. v. Pittsburgh \& L.E.R.R., 226 Pa. 391, 75 Atl. 596 (1910); Western Hatcheries v. Byrd, 218 S.W.2d 342 (Tex. Civ. App. 1949).

43. Courts in fact often seem unaware of, or ignore, their departures from precedent. E.g., compare Weiss v. Revenue Bldg. \& Loan Ass'n, 116 N.J.L. 208, 182 Atl. 891 (1936) with Hoag v. Jenan, 86 Cal. App. 2d 556, 195 P.2d 451 (1948) (attempting to distinguish Weiss). See also cases cited note 120 infra and text at notes $120-22$ infra.

44. See notes 8-12 supra and accompanying text; cases cited notes 25-28 supra.

45. See, e.g., United States v. Speed, 75 U.S. ( 8 Wall.) 77 (1868); Stoltenben v. General Foods Corp., 79 F. Supp. 228 (S.D.N.Y. 1948) ; Kelly v. Valley Constr. Co., 43 Wash. 2d 679, 262 P.2d 970 (1953). In some cases, however, the contract does not fix the price, see, e.g., Continental Copper \& Steel Industries, Inc. v. Bloom, 139 Conn. 700,96 A.2d 758 (1953) (cost-plus contract), or the quantity of goods sold, see, c.g., Kay Petroleum Corp. v. Piergrossi, 137 Conn. 620, 79 A.2d 829 (1951) (dealer's franchise) ; Joest v. John A. Denie's Sons Co., 174 Tenn. 410, 126 S.W.2d 312 (1939) (best efforts).

46. See, e.g., MacKenzie Laboratories, Inc. v. Lawrence, 80 F. Supp. 710 (D. Md. 1948) ; LaMiller v. St. Claire Packing Co., 99 Cal. App. 2d 518, 222 P.2d 75 (1950) ; Margaret Mill v. Aycock Hosiery Mills, 20 Tenn. App. 533, 101 S.W.2d 154 (1936).

47. Hinckley v. Pittsburgh Bessemer Steel Co., 121 U.S. 264 (1887) ; Hugo V. Loewi, Inc. v. Geschwill, 186 F.2d 849 (9th Cir.), cert. denied, 342 U.S. 817 (1951) ; Ahlbin v. Crescent Commercial Corp., 100 Cal. App. 2d 646, 224 P.2d 131 (1950). 
reason the seller entered the contract. 48 The certainty rule, in this context, has become a flexible standard of "reasonable certainty" $;{ }^{49}$ verdicts have been sustained although based upon opinion evidence of doubtful admissibility ${ }^{50}$ or upon liberal inference. ${ }^{51}$ No offer of evidence has recently been held too uncertain or speculative to be admitted.52 And modern courts have abandoned the severity of prior case law by developing two devices for avoiding the most difficult questions of allocating joint costs $;^{53}$ they have often defined costs to include only those items that would have increased had the contract been liept, ${ }^{54}$ and have refused to require detailed account by plaintiff of his costs,

48. Masterson v. Mayor of Brooklyn, 7 Hill 61 (N.Y. Sup. Ct. 1845); United States v. Behan, 110 U.S. 338 (1884) (dictum). One court has awarded compensation for loss of direct profits that it had held unforeseeable. Hugo V. Loewi, Inc. v. Geschwill, supra note 47.

49. See, e.g., Stentor Elec. Mfg. Co. v. Klaxon Co., 115 F.2d 268, 273 (3d Cir. 1940), rov'd other gronts, 313 U.S. 487 (1941); Eastern Ky. Lumber \& Development Co. v. Waddell, 239 S.W.2d 68, 71 ( $\mathrm{Ky} .1951$ ); cases cited notes 50-51 infra. The rule has also been treated as requiring only the best evidence "reasonably" available. Betterman v. American Stores Co., 367 Pa. 193, 207, 80 A.2d 66, 74 (1951) ; Bogart v. Pitchless Lumber Co., 72 Wash. 417, 130 Pac. 490 (1913).

50. Compare, e.g., Capital Paper Box, Inc. v. Belding Hosiery Mills, Inc., 350 Ill. App. 68, 111 N.E.2d 858 (1953) ; De Ponte v. Mutual Contracting Co., 18 N.J. Super. 142, 86 A.2d 785 (App. Div. 1952) ; Loughran v. Del Santo, 85 A.2d 179 (R.I. 1951), writh Haddad v. Western Contracting Co., 76 F. Supp. 987 (N.D. W. Va. 1948) ; cases cited note 126 infra.

51. See Reiss \& Weinsier, Inc. v. United States, 116 F. Supp. 562 (Ct. C1. 1953) (allocation of joint costs assumed) ; Kay Petroleum Corg. v. Piergrossi, 137 Conn. 620, 79 A.2d 829 (1951) (demand inferred) ; Freedom Oil Works Co. v. Williams, $302 \mathrm{~Pa} .51,152$ Atl. 741 (1930) (liquidated damages clause is evidence of profit margin); Quist v. Zerr, 12 Wash. 2d 21, 120 P.2d 539 (1941) (possible effect of war on gasoline supply ignored).

52. One court has suggested that a complaint would be bad on demurrer if the facts alleged did not indicate that direct profits could be proved. Atlantic Coast Realty Co. v. Townsend, 124 Va. 490, 508, 98 S.E. 684,690 (1919) (dictum), but later cases cast doubt upon the Townsend rationale. See Sullivan v. Sproule, 176 Kan. 274, 269 P.2d 1015 (1954); cf. Arnold v. Tarrant Beverage Co., 215 S.W.2d 894 (Tex. Civ. App. 1948).

Only four cases found in the last decade have denied recovery of a manufacturer's loss of direct profits. In two cases, the court, sitting without a jury, found plaintiff's evidence insufficient to support an award. Gruber v. S-M News Co., 126 F. Supp. 442 (S.D.N.Y. 1954) (best efforts contract breached; no proof of demand); MacKenzie Laboratories, Inc. v. Lawrence, 80 F. Supp. 710 (D. Md. 1948) (plaintiff's contradictory estimates of profit margin preclude recovery). One held that plaintiff's evidence was insufficient to go to the jury. Haddad v. Western Contracting Co., 76 F. Supp. 987 (N.D. W. Va. 1948) (plaintiff was losing money on construction contract at time of breach). The fourth summarily dismissed plaintiff's evidence, by analogizing it to Aesop's tale of the milkmaid and her pail. Western Hatcheries v. Byrd, 218 S.W.2d 342 (Tex. Civ. App. 1949).

53. In the only cases discussing allocation of joint costs, construction contractors' overhead costs were allocated solely on basis of total sales without comparison of actual costs to perform different contracts. Reiss \& Weinsier, Inc. v. United States, 116 F. Supp. 562 (Ct. Cl. 1953) ; Houston Ready-Cut House Co. v. United States, 96 F. Supp. 629 (Ct. Cl. 1951).

54. King Features Syndicate v. Courrier, 241 Iowa 870, 43 N.W.2d 718 (1950) ; Jessup \& Moore Paper Co. v. Bryant Paper Co., 297 Pa. 483, 147 Atl. 519 (1929), 78 U. PA. L. 
thereby shifting to defendant the burden of showing that plaintiff's computation is unjust. ${ }^{55}$ Thus a simpler standard of proof has been required of the manufacturer, and the middleman has been allowed to recoup his gross markup as loss of profits. ${ }^{56}$ Courts have also helped the manufacturer to recover direct profits by presuming that his supply exceeded his demand, or that he could have easily expanded his output to meet demand. ${ }^{57}$ The opposite presumption is made, however, when plaintiff is a middleman.5s Indeed, earlier courts seemed to feel that a middleman's sales were always substitute sales, ${ }^{50}$ but recent cases have at least permitted dealers to rebut the presumption by proving that in fact they were not. ${ }^{60}$

REv. 563. The value of plaintiff's time is treated as a variable cost. United States v. Speed, 75 U.S. (8 Wall.) 77 (1868); Geluska v. Scharoun, 87 N.Y.S.2d 381 (Sup. Ct. 1949); Carras v. Birge, 211 S.W.2d 998 (Tex. Civ. App. 1948). The propriety of including fixed costs is, however, sometimes treated as a question of fact. Dad's Root Beer v. Atkin, 90 F. Supp. 477 (E.D. Pa. 1950). See also Note, 99 U. PA. L. Rev. 229, 231-33 (1950).

55. Tucson Federal Sav. \& Loan Ass'n v. Aetna Inv. Corp., 74 Ariz. 163, 245 P.2d 423 (1952) ; United Press Ass'ns v. McComb Broadcasting Corp., 201 Miss. 68, 28 So. 2d 575, stggestion of error overruled, 201 Miss. 68, 30 So. $2 d 511$ (1947); Capital Paper Box, Inc. v. Belding Hosiery Mills, Inc., 350 I1l. App. 68, 111 N.E.2d 858 (1953).

56. Stolteben v. General Foods Corp., 79 F. Supp. 228 (S.D.N.Y. 1948) ; Patty v. Berryman, 95 Cal. App. 2d 159, 212 P.2d 937 (1949); Quist v. Zerr, 12 Wash. 2d 21, 120 P.2d 539 (1941).

57. Plaintiffs in lost profit actions normally have the burden of proving that they could not make substitute contracts in the market. Norwood Lumber Co. v. McKean, 153 F.2d 753 (3d Cir. 1946) ; Ahlbin v. Crescent Commercial Corp., 100 Cal. App. 2d 646, 224 P.2d 131 (1950). When plaintiff is a seller-manufacturer, however, he is not required to show that he was unable to make a substitute sale. Mt. Pleasant Stable Co. v. Steinberg, 238 Mass. 567, 131 N.E. 295 (1921) ; Cameron v. White, 74 Wis. 425, 43 N.W. 155 (1889); 5 CorbIN $\S \S 1039,1041$. The seller-manufacturer is thus aided by a presumption that substitute contracts could not be made. Some cases indicate, moreover, that the presumption is not rebuttable. See Mt. Pleasant Stable Co. v. Steinberg, supra (presumption rebuttable only in personal services contracts); Wolf v. Studebaker, $65 \mathrm{~Pa} .459$ (1870) (rebuttal opens too many collateral inquiries); Watson v. Gray's Harbor Brick Co., 3 Wash. 283, 28 Pac. 527 (1891). But cf. DeMoss v. Beryllium Corp., 358 Pa. 470, 474, 58 A.2d 70, 72 (1948) (dictum). The presumption is sometimes applied in the face of a strong possibility that plaintiff's supply was limited and that he was unable to expand. E.g., Oswego Falls Pulp \& Paper Co. v. Stecher Lithographic Co., 215 N.Y. 98, 109 N.E. 92 (1915) ; Alleghany Iron Co. v. Teaford, 96 Va. 372, 31 S.E. 525 (1898).

58. Ahlbin v. Crescent Commercial Corp., supra note 57; cases cited note 59 infra. Distributors of gasoline, however, seem to receive the favorable treatment usually reserved for manufacturers. See Kay Petroleum Corp. v. Piergrossi, 137 Conn. 620, 79 A.2d 829 (1951) (no discussion whether substitute buyers available) ; Freedom Oil Works Co. v. Williams, 302 Pa. 51, 152 Atl. 741 (1930) (same); Quist v. Zerr, 12 Wash. 2d 21, 120 P.2d 539 (1941) (same).

59. See Berger Mfg. Co. v. Phillips Hotel Operating Co., 89 S.W.2d 703 (Mo. Ct. App. 1935) ; Genovese v. A. Lenobel, Inc., 148 Misc. 548, 265 N.Y. Supp. 338 (N.Y. Munic. Ct. 1933), reళ'd other grounds, 154 Misc. 91, 275 N.Y. Supp. 521 (Sup. Ct., App. T. 1934). See also cases collected in Locks v. Wade, 36 N.J. Super. 128, 114 A.2d 875 (App. Div. 1955) ; 1 Bonbright, Valuation of Property 305 n.89 (1937) ; Annot., 24 A.L.R.2d 1008 (1952).

60. Lacks v. Wade, supra note 59; Smead v. Sutherland, 118 Vt. 363, 111 A.2d 335 (1955). 
The favored treatment of sellers' claims seems justified by the nature of the interests involved. Abandonment of the foreseeability rule as a restrictive standard is justified, not so much because the profits claimed are actually foreseeable by defendant, but because verdicts for unrealized direct profits can never be grossly disproportionate to the consideration defendant would have received for performing the contract. Contract price is the ceiling of recovery $^{, 1}$ and the largest cost items to be deducted from that price are the most susceptible to proof. $^{.2}$ As a result, there is seldom a danger of large overcompensation.

The relaxation of the certainty rule is justified as a means of compensating the expectation interest. The rather lax treatment of cost problems, combined with a presumption that manufacturers can always expand, does introduce a risk that plaintiff may receive somewhat more than his actual losses. But a rigorous rule of certainty would err more in the other directon, often preventing plaintiff from recovering any of the profits within his expectation interest. ${ }^{63}$ Showing demand, ability to expand, and allocation of joint costs entails timeconsuming and complex problems of proof; detailed certainty would be virtually unattainable. ${ }^{64}$ Since most of the data upon which costs of performance can be predicted is in the possession of the plaintiff, he should not be permitted to recover until he has introduced data from which those costs may be reasonably inferred. But defendant should be given access to plaintiff's records in order to verify the data, ${ }^{65}$ and once a reasonable basis for inference has been laid, the risk of non-persuasion as to precise amount should be placed on defendant. It should not be forgotten, that any uncertainty resulted from defendant's breach; it would be unfair to permit defendant to profit from that uncertainty in the litigation. ${ }^{66}$

61. See, c.g., Kelly v. Valley Constr. Co., 43 Wash. 2d 679, 262 P.2d 970 (1953). Contract price may occasionally depend upon a variable external factor and thereby become a question of fact. See, e.g., Betterman v. American Stores Co., $367 \mathrm{~Pa} .193,80$ A.2d 66 (1951) (cost plus contract); Ball v. Stokely Foods, 37 Wash. 2d 79, 221 P.2d 832 (1950) (quality of farm produce).

62. See, e.g., Stolteben v. General Foods Corp., 79 F. Supp. 228 (S.D.N.Y. 1948) (manufacturing and administrative costs proved by testimony of manufacturer and his accountant) ; Guidry \& Swayne v. Miller, 217 La. 935, 47 So. 2d 721 (1950) (cost of construction materials proved by records of payments to suppliers) ; Kelly v. Valley Constr. Co., supra note 61 (labor costs computed from prevailing union wage scales). See also National Industrial Conference Board, Costs and Profits in Manufacturing InDUSTRY (1935) (during 1914-1933 materials and labor averaged 55-66\% of manufacturers' receipts from sales of goods).

63. E.g., Western Hatcheries v. Byrd, 218 S.W.2d 342 (Tex. Civ. App. 1949).

64. Consolidated Flour Mills Co. v. File Bros. Wholesale Co., 110 F.2d 926 (10th Cir. 1940) (joint costs). See FTC, Report of the Consmission on Case Studies in Distributron Cost accounting for Manufacturing and Wholesaling, H.R. Doc. No. 287, 77th Cong., 1st Sess. (1941) (hereinafter cited as FTC Costs REPoRT) (costs); Nationax Industrial Conference Board Studies in Business Policies No. 77, Forecasting in INDUSTRY 59-68 (1956) (demand).

65. Cf. cases cited note 197 infra. 
Modern case law relaxing the certainty rule and facilitating the recovery of lost profits also affords greater protection of the reliance interest. Sellers normally incur substantial expenses in reliance on and in preparation for timely performance of their contracts. ${ }^{67}$ Courts universally try to protect "out-of-pocket" reliance costs. ${ }^{68}$ But in point of fact reliance expenditures are extremely difficult and speculative to assess. For reliance expenditures often consist of overhead expenses and other joint costs that cannot easily be allocated to any particular contract. ${ }^{69}$ In addition, the seller operating near capacity may have foregone opportunities to enter similar contracts with others $;^{70}$ the amount of his reliance interest should then include the value of the opportunities foregone (opportunity cost). ${ }^{71}$ If damages were limited to the reliance interest, therefore, no greater certainty would be attained. ${ }^{72}$ In addition, an action for lost profits is really an action to recover the reliance interest; plaintiff's reliance is prompted by his expectation of profits and the amount of profit anticipated is usually the measure of the reliance.

Another reason supporting favored treatment of seller's claims is that lost profits can often be measured directly without encountering difficult problems of proof. If plaintiff has an established course of business he can usually offer

66. Stentor Elec. Mfg. Co. v. Klaxon Co., 115 F.2d 268 (3d Cir. 1940), rev'd other grounds, 313 U.S. 487 (1941); Smith v. Mendonsa, 108 Cal. App. 2d 540, 238 P.2d 1039 (1952) ; Restatearent, Contracts $\$ 331$, comment $a$ (1932).

67. See, e.g., Wright v. Ickenroth, 215 S.W.2d 43 (Mo. Ct. App. 1948); Smead v. Sutherland, 118 Vt. 361, 111 A.2d 335 (1955); cases cited note 9 supra.

68. United States v. Behan, 110 U.S. 338 (1884); Goodman v. Dicker, 169 F.2d 684 (D.C. Cir. 1948); see 5 Conbin $\$ \$ 1031-35$; Fuller \& Perdue, The Reliance Interest in Contract Damages, 46 Y ALE L.J. 52, 373 (1936-37).

69. See, e.g., cases cited notes 53-54 supra (allocation of manufacturer's overhead); FTC COSTS REPORT 1-48, 60-72, 88-112 (joint distribution costs).

70. See Jessup \& Moore Paper Co. v. Bryant Paper Co., 297 Pa. 483, 492, 147 At1. 519, 523 (1929).

71. Lost-opportunity cost is universally recognized by economists as a cost of doing business. Blodgett, Principles of Economics 238-39 (2d ed. 1946) ; Cairncross, Introduction to Economics 253-55 (2d ed. 1951) ; Gearasel, Fundamentals of Econonics 349-55 (4th ed. 1943). It is a forbearance which must be considered to measure a plaintiff's total reliance. Fuller \& Perdue, supra note 68 , at 60,61 . Opportunity cost is probably more important in the manufacturers' than dealers' situation: the manufacturer may be presumed to be able to expand his plant capacity, see note 57 supra and accompanying text, but often, when operating near capacity, he will forego some opportunities rather than incur the capital expenses of expansion. The dealer, however, can generally expand capacity simply by ordering more goods; his expansion seldom requires the capital outlay a manufacturer must incur. Therefore, at least in markets where supply exceeds demand, he is not as likely to forego other opportunities in reliance on the contracts he has.

72. Consolidated Flour Mills Co. v. File Bros. Wholesale Co., 110 F.2d 926, 930 (10th Cir. 1940) (joint costs) ; Fuller \& Perdue, supra note 68, at 61-62; notes 69-71 supra and accompanying text. Proving opportunity costs involves the same elements encountered in determining the amount by which an injured party was able to mitigate damages. Cf. Harris v. National Union of Marine Cooks, 116 Cal. App. 2d 759, 254 P.2d 673 (1953) (mitigation problems). 
records of similar past contracts showing data of past profit margins and performance expenses. ${ }^{73}$ These figures enable courts to deduct from an established gross margin of profit those expenses necessary to complete performance which plaintiff did not actually incur. ${ }^{74}$

Courts have been less favorable to claims of middlemen-sellers than to those of manufacturers; yet the general reasons for favoring sellers' claims are equally applicable. The reliance and expectation interests are just as deserving of protection and the problems of proving them directly are as difficult. ${ }^{75}$ The desirability of deterring breach seems just as great and the defendant's safeguards against excessive verdicts are as effective. There is, in addition, less reason to apply the market formula; other contracts are not really substitutes but could probably have been made in any event. Indeed, a middleman's ability to obtain added goods from one of several suppliers seems more probable than a single manufacturer's ability to expand his plant capacity. On the other hand, for that very reason, it is easier for a middleman than for a manufacturer to show excessive supply. Since the evidence necessary to prove this fact would be more accessible to the seller than to the defendant, it might be preferable in this context to retain the presumption that subsequent sales were substitute sales, so long as the presumption were freely rebuttable. The trend of recent decisions indicates that the law is moving towards recognition of this conclusion, if not the reasoning advanced on its behalf.

\section{Buyers' Claims for Collateral Profits \\ Middlemen's Claims for Resale Profits}

The middleman-buyer bases his claim on the theory that the supplier's breach prevented him from realizing the profit of reselling the contract goods to his

73. See notes $25-27$ supra and accompanying text.

74. Houston Ready-Cut House Co. v. United States, 96 F. Supp. 629 (Ct. C1. 1951) (costs) ; Eastern Ky. Lumber \& Development Co. v. Waddell, 239 S.W.2d 68 (Ky. 1951) (profit margin).

75. See Tucson Federal Sav. \& Loan Ass'n v. Aetna Inv. Corp., 74 Ariz. 163, 245 P.2d 423 (1952) (overhead) ; A. Lenobel, Inc. v. Senif, 252 App. Div. 533, 300 N.Y. Supp. 226 (2d Dep't 1937) (overhead allocation) ; Nelson Equipment Co. v. Harner, 191 Ore. 359, 230 P.2d 188 (1951) (lost opportunities).

A special allocation problem arises in measuring a dealer's reliance. Since a dealer makes most of the expenditures essential to his performance before entering the contract with defendant, it appears that there is little reliance interest. But inventory replacements and other expenditures are made in light of current as well as future sales. Therefore a dealer's reliance interest should equal his total cost to prepare to sell to defendant minus any value retained after the breach. Recovery should at least equal total overhead allocable to the particular contract plus any inventory loss suffered (actual outlay minus present cost to buy equivalent goods); for inability to make a substitute sale renders past overhead expenditures useless after the breach, and retained value therefore is solely the inventory value to plaintiff after breach.

Proof of the reliance interest would often be at least as difficult to prove as loss of profits. The difficulty of allocating reliance in general to reliance on a particular contract presents an added argument for awarding these expenses as part of the compensation for the expectation interest. Cf. Fuller \& Perdue, supra note 68, at 60-63. 
customers at a price greater than his cost. ${ }^{76}$ Proof of the number of sales lost, the price at which they would have been consummated and the cost of reselling them may require extensive evidence.

The most substantial part of the middleman's costs is the price at which defendant promised to supply him with goods; this is usually established simply by proving the terms of the contract breached. ${ }^{77}$ However, plaintiff's selling costs also include general merchandising, delivery and advertising costs ${ }^{78}$ which cannot easily be allocated to particular sales.79 The cost of selling brand-named goods includes items which are unusually difficult to measure. A dealer often spends considerable amounts to advertise the brands he carries. ${ }^{80}$ The unit cost of advertising expenses must be allocated if the dealer, after breach, attempts to compute the cost of making future sales of defendant's brand. But, aside from the usual difficulties of allocating general expenses to specific goods, a significant part of the plaintiff's advertising expenses is incurred in order to enhance his reputation by linking his name with the good will of the manufacturer's brand name. ${ }^{81}$ Since these expenses of building reputation would have had a cumulative effect had there been no breach, the amount of advertising necessary to continue selling under defendant's franchise would have decreased. As a result, estimates of costs that would have been incurred but for breach should be reduced accordingly. If plaintiff is able to obtain a substitute franchise, his business reputation gained while selling under the defendant's franchise endures to some extent despite the breach. Thus, past expenses made to enhance reputation may have a present value to plaintiff which should be deducted from his recovery. ${ }^{\$ 2}$ These issues have not yet been litigated in lost profits cases, but, if fair-trading

76. Davis v. Koppers Co., 335 Mich. 9, 55 N.W.2d 152 (1952) ; Inland Products Corp. v. Donovan, Inc., 240 Minn. 365, 62 N.W.2d 211 (1953); Sellers v. Orona, 58 N.M. 53, 265 P.2d 369 (1954).

77. See, e.g., Hill's, Inc. v. William B. Kessler, Inc., 41 Wash. 2d 42, 246 P.2d 1099 (1952) (contract price sixty per cent of resale price).

78. See, e.g., Goodman v. Dicker, 169 F.2d 684 (D.C. Cir. 1948) (promotion costs); Walpole v. Prefab Mfg. Co., 130 Cal. App. 2d 472, 230 P.2d 36 (1951) (fixed overhead); Inland Products Corp. v. Donovan, Inc., 240 Minn. 365, 62 N.W.2d 211 (1953) (freight charges).

79. FTC Costs Report (passim); Comment, 65 Yale L.J. 34, 43 (1955).

80. See, e.g., Phalanx Air Freight, Inc. v. National Skyway Freight Corp., 104 Cal. App. 2d 771, 232 P.2d 510 (1951) (plaintiff advertised as defendant's forwarding agent); New Haven Evening Register, Feb. 28, 1956, p. 20 (department store advertised "Brand Names Week").

81. A related problem faces the dealer who has used a third party's brand-named product as a loss leader during the term of his contract with defendant. Since a loss leader campaign increases demand for both the loss leader and other goods carried by the dealer, and also increases the dealer's good will, part of the cost of the campaign is a prepaid expense of future sales of defendant's (and others') goods, and part is a cost of past sales. See Paton, Accountants' Handbook 336 (3d ed. 1945).

82. On the other hand, consumer identification of the plaintiff with one product may lessen his ability to sell a substitute product to the public. 
continues, they may become significant in cases involving dealers of tradenamed items.

The loss of gross income from future sales often raises even more difficult problems for the courts. If defendant has breached a contract to sell a specific quantity of goods, plaintiff can often prove the price at which he would have resold them simply by introducing a specific contract of resale, ${ }^{83}$ or by establishing the price in his resale market at the time of breach. ${ }^{84}$ On the other hand, plaintiff may sue for total breach of a franchise or dealership contract. ${ }^{85}$ Since many franchises and dealership arrangements do not limit the quantity of goods the dealer may buy, the plaintiff must establish both the probable resale price he could have maintained and number of sales he could have made at that price during the term of the contract. ${ }^{86}$ Neither can be predicted with assurance, even during the relatively short term of most franchises, ${ }^{87}$ for the quantity varies with the price at which the goods would have been offered, ${ }^{88}$ and both quantity and price vary with future changes in consumer purchasing power and consumer preferences. ${ }^{89} \mathrm{~A}$ similar problem exists even if the dealer can obtain a substitute franchise to sell the goods of defendant's competitors. The amount of his loss then depends upon the comparative demand for the two products and the comparative cost at which they could be sold. ${ }^{90}$ Comparative cost is generally a function of the amount of each product

83. See, e.g., Murarka v. Bachrack Bros., Inc., 215 F.2d 547 (2d Cir. 1954) ; Martin \& Turner v. Continental Chain Corp., 113 F. Supp. 61 (E.D. Pa. 1953) ; Piekarsky v. Rossman, 95 F. Supp. 748 (M.D.N.C. 1951). Plaintiff may also show orders received from prospective buyers. Norwood Lumber Corp. v. McKean, 153 F.2d 753 (3d Cir. 1946); Selig v. Wunderlich Contracting Co., 160 Neb. 215, 69 N.W.2d 861 (1955). Contra Busam Motor Sales, Inc. v. Ford Motor Co., 85 F. Supp. 790,796 (S.D. Ohio 1949) (dictum).

S4. E.g., American Pulp \& Paper Co. v. Denenberg, 132 F. Supp. 802 (E.D. Pa. 1955); Davis v. Koppers Co., 335 Mich. 9, 55 N.W.2d 152 (1952); Pace Corp. v. Jackson, 275 S.W.2d 849 (Tex. Civ. App. 1955).

85. About $40 \%$ of all suits brought by middlemen against their suppliers, reported 1946-56, were breach of franchise or distributorship contract cases. Of the remaining $60 \%$, perhaps $25 \%$ may have involved parties that had a continuing buyer-seller relationship, but only in Pace Corp. v. Jackson, supra note 84, is there any definite indication of such relationship.

86. Smith v. Onyx Oil \& Chemical Co., 120 F. Supp. 674 (D. Del. 1954), modified, 218 F.2d 104 (3d Cir. 1955) ; Busam Motor Sales, Inc. v. Ford Motor Co., 85 F. Supp. 790 (S.D. Ohio 1949) ; Gilmore v. American Gas Mach. Co., 129 N.E.2d 93 (Ohio C.P. 1952).

87. Many franchises run from year to year. See, e.g., Stoves, Inc. v. Tennessee Enamel Mfg. Co., 89 F. Supp. 825 (M.D. Tenn. 1950); Time, Dec. 19, 1955, p. 86.

88. See, c.g., Sanuelson, Econonics, An InTroductory Analysis cc. $19-21$ (1948).

89. Ibid. Other factors, such as technological chariges or shortages of related materials, will also affect future sales. See, c.g., Gilmore v. American Gas Mach. Co., 129 N.E.2d 93 (Ohio C.P. 1952). For review of current methods used to predict future sales, and the accuracy obtained, see National Industrial Conference Board Studies in Business Polxcy No. 77, Forecasting IN INDUstry (1956).

90. A "substitute franchise" may not provide the dealer with goods that are sufficiently comparable to warrant measuring his damages by the change in market price between contract time and breach. Orester v. Dayton Rubber Mfg. Co., 228 N.Y. 134, 126 N.E. 510 
that could be sold; ${ }^{91}$ and since one or both products may be fair-traded, the amount that could be sold may depend upon such variables, as both manufacturers' pricing and advertising policies.

The case law today generally accords the buyer's claims for resale profits favorable treatment analogous to that of the seller's claims for direct profits. The certainty rule is equally relaxed : "estimates" and "fair probabilities" have sufficed $; 92$ both cost and demand have been proved by opinion evidence ${ }^{03}$ or by inferences freely drawn from records of past sales. ${ }^{94}$ When difficult demand problems arise, they are generally overlooked. For example, courts are reluctant to base damages upon the "value of the chance" lost 95 - to award a percentage of the estimated profits in proportion to the probability that plaintiff would have earned them-but partial recovery of possible resale profits has been awarded to a middleman who was not able to prove that he could

(1920). For a contract to obtain Local Cola is not a substitute for a franchise with CocaCola, even if both cost the dealer 3 cents and retail for 5 cents, if Coca-Cola outsells the other ten to one.

Nevertheless, breach may enable a dealer to sell brand goods which he would not have been able to carry alongside defendant's goods. See, e.g., Ross v. Frank W. Dunne Co., 119 Cal. App. 2d 690, 260 P.2d 104 (1953). The amount of profit a dealer can make by acquiring new lines must therefore be subtracted from the profit expected from defendant's goods. Restatement, Contracts $\$ 336$, comment $a$ on subsection (1) (1932).

91. The per-unit cost of selling added units almost always decreases as more units are sold. See authorities cited in Comment, 65 YALE L.J. 34, 78 n.255 (1955). Thus if the plaintiff-dealer could maintain the same resale markup on the substitute brand as on dt:fendant's goods, but could sell more units of defendant's goods, his overhead costs would be more per unit on the substitute brand.

92. Smith v. Onyx Oil \& Chemical Co., 218 F.2d 104 (3d Cir. 1955) ; Ross v. Frank W. Dunne Co., 119 Cal. App. 2d 690, 260 P.2d 104 (1953) ; Industrial Natural Gas Co. v. Sunflower Natural Gasoline Co., 330 11l. App. 343, 71 N.E.2d 199 (1947). The test is usually stated to be "reasonable certainty." Standard Mach. Co. v. Duncan Shaw Corp., 208 F.2d 61 (1st Cir. 1953) ; Black v. Love \& Amos Coal Co., 30 Tenn. App. 377, 206 S.W.2d 432 (1947) ; Hole v. Unity Petroleum Corp., 15 Wash. 2d 416, 131 P.2d 150 (1942).

93. Smith v. Onyx Oil \& Chemical Co, 120 F. Supp. 674 (D. Del. 1954), madificd, 218 F.2d 104 (3d Cir. 1955) (costs) ; Lighthouse Trailer Co. v. Foster, 33 So. 2d 540 (La. App. 1947) (demand) ; Sheldon-Seatz, Inc. v. Coles, 319 Mich. 401, 29 N.W.2d 832 (1947) (demand) ; Black v. Love \& Amos Coal Co., supra note 92 (both). But see Emrich Motors Corp. v. General Motors Corp., 181 F.2d 70 (7th Cir. 1950) (dealer's estimate of demand) ; Roberts Distributing Co. v. Kaye-Halbert Corp., 126 Cal. App. 2d 664, 272 P.2d S86 (1954) (plant manager's opinion established repair costs, but not selling costs).

94. Smith v. Onyx Oil \& Chemical Co., supra note 93; Selig v. Wunderlich Contracting Co., 160 Neb. 215, 69 N.W.2d 861 (1955) ; Hole v. Unity Petroleum Corp., 15 Wash. 2d 416,131 P.2d 150 (1942).

95. E.g., 25 Fifth Ave. Management Co. v. Ivor B. Clark, Inc., 280 App. Div. 205,112 N.Y.S.2d 117 (1st Dep't 1952) ; Notes, 28 ColuM. L. Rev. 76 (1928), 46 Harv. L. Rev. 696, 699 (1933). But cf. Matthews v. Continental Roll \& Steel Foundry Co., 121 F.2d 594 (3d Cir. 1941) (exclusive right to develop and exploit patent has value even though effort may result in profit or loss). Courts do, however, award value of the chance damages when defendant's duty to perform was conditioned upon the occurrence of a future event. 5 Corbin $\$ 1030$. 
have sold the volume necessary to keep his contract with the defendant. ${ }^{96}$ Overhead and other selling costs have been given inconsistent treatment. Some courts have required that both fixed and variable costs should be subtracted from the middleman's gross markup $;^{97}$ others have subtracted only variable

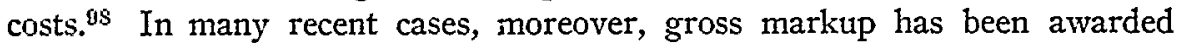
without any deductions $; 9$ other cases have indirectly reached the same result by applying the general damages rule of market price minus contract price but determining "market price" on the basis of the market to which the middleman sells. ${ }^{100}$

Even more significant is the decreasing effect of the foreseeability rule as a limitation on damages. Older cases conditioned defendant's liability on a showing that defendant had notice at the time of contract either of an existing resale contract or of the size of resale profits anticipated. ${ }^{101}$ Modern courts, relying on the older authority, sometimes reach similar results, ${ }^{102}$ but many have tended to eliminate the notice requirement. Lost profits have been awarded on the basis of resale contracts made subsequent to the contract with defendant; ${ }^{103}$ recovery has often been allowed when no resale contract was made. ${ }^{104}$ Indeed some cases have suggested that resale profits are foreseeable per se when defendant contracted to sell a large quantity of goods or when he knew

96. Smith v. Onyx Oil \& Chemical Co., 120 F. Supp. 674 (D. Del. 1954), modified, 21s F.2d 104 (3d Cir. 1955). But cf. De Fiore v. Peffers, 124 N.E.2d 733 (Ohio Ct. App. 1955).

97. E.g., Transit Advertisers, Inc. v. New York, N.H. \& H.R.R., 194 F.2d 907 (2d Cir.), ccrt. denicd, 344 U.S. 817 (1952) ; Busam Motor Sales, Inc. v. Ford Motor Co., $\$ 5$ F. Supp. 790, 796-97 (S.D. Ohio 1949) (dictum); Olcese v. Davis, 124 Cal. App. 2d 58, 268 P.2d 175 (1954).

98. Phalanx Air Freight, Inc. v. National Skyway Freight Corp., 104 Cal. App. 2d 771, 232 P.2d 510 (1951); Davis v. Koppers Co., 335 Mich. 9, 55 N.W.2d 152 (1952); Inland Praducts Corp. v. Donovan, Inc., 240 Minn. 365, 62 N.W.2d 211 (1953).

99. E.g., Walpole v. Prefab Mfg. Co., 103 Cal. App. 2d 472, 230 P.2d 36 (1951) ; Patco Products, Inc. v. Wilson, 5 N.J. 543, 76 A.2d 677 (1950) ; Hill's Inc. v. William B. Kessler, Inc., 41 Wash. 2d 42, 246 P.2d 1099 (1952).

100. See cases discussed 1 Bonbright, Valuation of Property 296-300 (1937).

101. C. F. Bonsor \& Co. v. Simon Rice Milling Co., 151 La. 1094, 92 So. 711 (1922); American Nat'l Bank v. Barley, 219 Mich. 482, 189 N.W. 22 (1922); Pope v. Ferguson, \$2 N.J.L. 566, \$3 Atl. 353 (1912).

102. Oxford Sporting Goods Mffg. Co. v. Gillman, 97 Ohio App. 269, 125 N.E.2d 214 (1953).

103. Mirarka v. Bachrack Bros., Inc., 215 F.2d 547 (2d Cir. 1954) ; Walpole v. Prefab Mig. Co., 103 Cal. App. 2d 472, 230 P.2d 36 (1951) ; Industrial Natural Gas Co. v. Sunflower Natural Gasoline Co., 330 I1l. App. 343, 71 N.E.2d 199 (1947).

104. E.g., Davis v. Koppers Co., 335 Mich. 9, 55 N.W.2d 152 (1952); Hole v. Unity Petroleum Corp., 15 Wash. 2d 416, 131 P.2d 150 (1942). Moreover, resale profits have been awarded to retailers and to dealers who seldom, if ever, would be able to prove existing resale contracts. See, e.g., Stoves, Inc. v. Tennessee Enamel Mfg. Co., 89 F. Supp. 825 (M.D. Tenn. 1950) (breach of dealer's franchise); Levin's Auction Exchange v. Samuels, 28 So. 2d 340 (La. App. 1946) (retailer) ; Sheldon-Seatz, Inc. v. Coles, 319 Mich. 401, 29 N.W.2d 832 (1947) (breach of dealer's franchise). 
that the plaintiff was a merchant. ${ }^{105}$ The courts have not, however, departed from the rule requiring specific notice when unusually large resale profits were anticipated by the middleman. ${ }^{106}$

The nature of buyers' claims for resale profits warrants the favorable treatment now accorded them. By moving toward a presumption of foreseeability, and by relaxing the certainty requirements, the courts have of course increased the possibilities of large recoveries and overcompensation of some plaintiffs. In addition, as long as courts allow gross markups as damages, or permit the use of a market formula based upon the price in the market to which the middleman sells, selling costs will be understated and recovery will accordingly be too great. However, there are inherent safeguards against these dangers. The amount of recovery. is limited by the price prevailing in the middleman's resale market. Records of the dealer's past profit margin often provide an additional check on the size of the award ${ }^{107}$ when the profit margin has been unusually high, courts have cut off recovery. ${ }^{108}$ Moreover, the risk of some overcompensation is preferable to the risk that the plaintiff will not be reimbursed at all. Rigorous insistence on certainty would often prevent recovery of any lost profits.

105. Martin \& Turner v. Continental Chain Corp., 113 F. Supp. 61 (E.D. Pa. 1953); Appliance, Inc. v. Queen Stove Works, Inc., 228 Minn. 55, 36 N.W.2d 121 (1949) ; Hill's Inc. v. William B. Kessler, Inc., 41 Wash. 2d 42, 246 P.2d 1099 (1952). Contra Newspaper Readers Service, Inc. v. Canonsburg Pottery Co., 81 F. Supp. 99 (W.D. Pa. 1948) ; sec Werfel v. United States, 83 F. Supp. 507 (S.D.N.Y. 1948).

One case has pointed out that constructive notice based on the mercantile nature of the contract could swallow the entire foreseeability rule. Czarnikow-Rionda Co. v. Federal Sugar Refining Co., 255 N.Y. 33, 173 N.E. 913 (1930). If constructive notice of this type is not allowed, defendant must also be able to foresee that plaintiff cannot make a substitute contract in the market. Ibid. But since businessmen presumably know the conditions prevailing in the markets in which they bargain, the Czarnikozv-Rionda rationale applies only when inability to make a substitute contract arises from plaintiff's special circumstances rather than from prevailing market conditions. Murarka v. Bachrack Bros., Inc., 215 F.2d 547 (2d Cir. 1954).

106. Newspaper Readers Service, Inc. v. Canonsburg Pottery Co., supra note 105; 5 Corbin § 1015. But see Piekarsky v. Rossman, 95 F. Supp. 748 (M.D.N.C. 1951) (resale to "gray market"; no indication that defendant knew size of profit anticipated).

107. See, e.g., Transit Advertisers, Inc. v. New York, N.H. \& H.R.R., 194 F.2d 907 (2d Cir.), cert. denied, 344 U.S. 817 (1952) ; Smith v. Onyx Oil \& Chemical Co., 120 F. Supp. 674 (D. Del. 1954), modified, 218 F.2d 104 (3d Cir. 1955) ; Black v. Love \& Amos Coal Co., 30 Tenn. App. 377, 206 S.W.2d 432 (1947).

108. Osmose Wood Preserving Co. of Canada v. Osmose Wood Preserving Co. of America, 74 F. Supp. 435 (W.D.N.Y. 1947) (trial court sitting without jury). Juries also seem to discount evidence when it tends to establish a profit margin which exceeds their own notion of what plaintiff's profit should have been. See Mergert v. Bauman, 206 Okla. 651,246 P.2d 355 (1952) (profit from operating combine during harvest season); Robbins v. Trotter, 203 Okla. 68, 217 P.2d 1027 (1950) (same). When, however, the jury is not familiar with plaintiff's business, it may overestimate plaintiff's normal profit margin. See Forbes, Jan. 15, 1956, p. 14 (school teachers polled guessed brokers' commissions from $320 \%$ to $5,900 \%$ above actual figure). 
The future course of claims for lost resale profits has not yet been indicated by the courts. Less rigorous adherence to foreseeability and certainty requirements has enabled middlemen to obtain increasing success in claims against breaching suppliers. The most difficult questions of comparative demand and joint cost allocation have, however, not yet been raised. ${ }^{109}$ If these problems are presented, courts may conclude that the dealer's loss is too "contingent, speculative or remote." More likely, however, the courts will either allow increased use of expert opinion to overcome these difficulties or refuse to permit defendants to profit from the uncertainties created by their own breaches. ${ }^{110}$

\section{Manufacturers' Claims for Collateral Profits}

The problem of excessive damages is high-lighted when plaintiff is a buyer who expected to use the contract goods promised by defendant in order to process or manufacture other goods. By failing to deliver capital goods or essential raw materials, or by delivering them late, defendant often causes plaintiff temporarily to lose the profits of an established plant or enterprise, ${ }^{111}$ and sometimes delays the establishment of a new business venture when time is of the essence. ${ }^{112}$ Full compensation would often put on defendant a burden grossly disproportionate to the benefit he expected to receive from the contract. For the goods defendant promised to deliver may be necessary to one step of an otherwise vertically integrated undertaking ;13 they may be capital goods

109. By failing to raise questions of plaintiff's ability to mitigate, defendants have permitted courts to escape comparative demand and comparative cost problems. See, e.g., Standard Mach. Co. v. Duncan Shaw Corp., 208 F.2d 61 (1st Cir. 1953) (before breach defendant had offered to sell contract for supplying plaintiff to competitor; no question raised of plaintiff's ability to mitigate by contracting with that, or another, competitor). Despite the fact that most cases involve consumer goods sold competitively, see cases cited notes 76-108 supra, ability to mitigate has been raised in only one recent franchise case, Hole v. Unity Petroleum Corp., 15 Wash. 2d 416, 131 P.2d 150 (1942); the court held that defendant did not prove that plaintiff could obtain a substitute franchise on comparable credit terms.

Joint cost allocation problems have also been present in the cases, but were not raised by defendants. See, e.g., Phalanx Air Freight, Inc. v. National Skyway Freight Corp., 104 Cal. App. 2d 771, 232 P.2d 510 (1951) (freight forwarding agent reimbursed for costs of advertisements identifying defendant as carrier, without allocation of cost to establish agent's reputation).

110. See note 55 supra and accompanying text.

111. See, e.g., Stimac v. Wissman, 342 Mich. 20, 69 N.W.2d 151 (1955).

112. See, c.g., Flug v. Craft Mfg. Co., 3 Ill. App. 2d 56, 120 N.E.2d 666 (1954) (failure to deliver dies needed for manufacture). Breach of warranty often produces similar results. Sce, c.g., Dally v. Isaacson, 40 Wash. 2d 574, 245 P.2d 200 (1952) (breach delays construction).

113. See, e.g., Rich v. Bongiovanni, 4 N.J. Super. 243, 66 A.2d \&8S (App. Div. 1949).

Similarly, plaintiff may have needed the goods to meet a contract of resale; failure to met the contract may expose plaintiff to liability to the third party, possibly including profits lost by the latter. Plaintiffs would, of course, want reimbursement for damages thus incurred. See, c.g., Dally v. Isaacson, supra note 112. 
essential to an assembly line production of consumers' goods. ${ }^{114}$ In addition, measuring the amount of loss combines the middleman's problem of proving resale demand with the seller-manufacturer's problem of proving cost. ${ }^{115}$ Both problems, moreover, may be more acute.

Manufacturers' claims also raise difficult questions of proving demand and cost. Unit production costs vary freely with the quantity of goods produced ;10 in turn, production, seldom limited by the contract breached, is eventually determined by consumer demand. ${ }^{117}$ Furthermore, many collateral profits cases involve plaintiffs who planned to produce a new product or to promote a new or expanded enterprise. ${ }^{118}$ Since demand then depends upon plaintiff's success in changing consumer buying habits, and costs on his productive skills, records of any past operations are less reliable bases for predicting future profits. ${ }^{10}$

Judicial treatment of claims for collateral profits is unpredictable, but generally unfavorable. The courts continue to require that the plaintiff's profits be foreseeable by the defendant at the time the contract was made. A few recent cases have held that the nature of the contract alone gave defendant sufficient notice to satisfy the foreseeability test, ${ }^{120}$ but most courts have either defined foreseeability in arbitrary fashion ${ }^{121}$ or else have required actual notice

114. See, e.g., Flug v. Craft Mfg. Co., 3 Ill. App. 2d 56, 120 N.E.2d 666 (1954).

115. See, e.g., Western Union Tel. Co. v. R. J. Jones \& Sons, 211 F.2d 479 (5th Cir. 1954) ; George W. Garig Transfer, Inc. v. Harris, 226 La. 117, 75 So. $2 d 28$ (1954) ; Biothermal Process Corp. v. Cohu \& Co., 119 N.Y.S.2d 158 (Sup. Ct. 1953), modified, 283 App. Div. 60, 126 N.Y.S.2d 1 (1st Dep't 1953), aff'd mem., 308 N.Y. 689, 124 N.E.2d 323 (1954). Often, however, either demand or major costs can be shown by proving collateral contracts. See, e.g., Addison Miller, Inc. v. United States, 70 F. Supp. 893 (Ct. Cl.), crrt. denied, 332 U.S. 836 (1947) (demand) ; Burge Ice Mach. Co. v. Strother, 273 S.W.2d 479 (Tenn. 1954) (costs).

116. E.g., Chamiberlin, The Theory of Monopolistic Conipetition 20-21, 230-35 (5th ed. 1946) ; Doyle, Economics of Business Enterprise cc. 7-8 (1952).

117. See, e.g., King v. Gerold, 109 Cal. App. 2d 316, 240 P.2d 710 (1952).

118. See Chain Belt Co. v. United States, 115 F. Supp. 701 (Ct. Cl. 1953) ; Evergreen Amusement Corp. v. Milstead, 206 Md. 610, 112 A.2d 901 (1955); Burge Ice Mach. Co. v. Strother, 273 S.W.2d 479 (Tenn. 1954).

119. Dieffenbach v. McIntyre, 208 Okla. 163, 254 P.2d 346 (1952). But see Stott v. Johnston, 36 Cal. 2d 864, 229 P.2d 348 (1951), reversing 219 P.2d 845 (Cal. Dist. Ct. App. 1950) (past records used to prove amount of expansion prevented by breach).

120. Schlottman v. Pressey, 195 F.2d 343 (10th Cir.), cert. denied, 344 U.S. 817 (1952) (contract to sell oil well casing); Chain Belt Co. v. United States, 115 F. Supp. 701 (Ct. Cl. 1953) (contract to sell plant); Dwyer v. Wiley Hotel Co., 91 Ohio App. 525, 108 N.E. 2d 859 (1952) (contract to lease restaurant space and equipment). See also Victoria Laundry, Ltd. v. Newman Industries, Ltd., [1949] 2 K.B. 528 (C.A.) (profits foreseeable solely from nature of contract are general damages).

121. The classic case is Smeed v. Foord, 1 El. \& El. 602, 120 Eng. Rep. 1035 (Q.B. 1859) (fall of rain foreseeable, but fall of market unforeseeable, since market moves in both directions). Its subtle distinction has not been lost on modern courts. See Oxford Sporting Goods Mfg. Co. v. Gillman, 97 Ohio App. 269, 125 N.E.2d 214 (1953) (fall of market for sweaters delivered late in season held unforeseeable). See also, e.g., Richardson v. Crone, 127 Mont. 200, 258 P.2d 970 (1953) (failure to harvest plaintiff's crops; defendant could not foresee that crops would be lost in thunderstorm); Burge Ice Mach. Co. v. Strother, 
of the specific profits expected. ${ }^{122}$ Nor has there been any appreciable relaxation of the certainty requirement. The verbal definition of the rule has changed from absolute to "reasonable" certainty ;123 the evidence supporting an award has occasionally been no more substantial than in the most liberal of the direct or resale profits cases. ${ }^{124}$ But the bulk of the recent decisions indicate that the change is only semantic. ${ }^{125}$ Past records and opinion evidence have been held too speculative to be admissible, ${ }^{126}$ or, if admitted, too contingent to support a verdict. ${ }^{127}$ In addition, the courts have sometimes treated

273 S.W.2d 479 (Tenn. 1954) (seller could not foresee buyer might use freezing unit, ordered for strawberry season, in order to freeze turkeys) ; Dally v. Isaacson, 40 Wash. $2 \mathrm{~d}$ 574, 245 P.2d 200 (1952) (not foreseeable that failure to do millwork would delay construction work not usually done until millwork is finished).

122. Flug v. Craft Mfg. Co., 3 Ill. App. 2d 56, 120 N.E.2d 666 (1954) ; Arkwright Mills v. Clearwater Mfg. Co., 217 S.C. 530, 61 S.E.2d 165 (1950). Similarly, courts have denied recovery for loss of profits expected from collateral contracts made subsequent to the contract with defendant. Macchia v. Megow, 355 Pa. 565, 50 A.2d 314 (1947); Burge Ice Mach. Co. v. Weiss, 219 F.2d 573, 582 (6th Cir. 1955) (dictum).

123. See, e.g., Dwyer v. Wiley Hotel Co., 91 Ohio App. 525, 108 N.E.2d 859 (1952) ; California Eastern Airlines, Inc. v. Alaska Airlines, Inc., 38 Wash. 2d 378, 229 P.2d 540 (1951) ; Stimac v. Wissman, 342 Mich. 20,69 N.W.2d 151 (1955) (mathematical certainty nat required) ; District News Co. v. Goldberg, 107 A.2d 375 (D.C. Munic. Ct. App. 1954) (same); Silvey v. Johnston, 193 Va. 677, 70 S.E.2d 280 (1952) ("intelligent estimate" sufficient) ; Gallagher v. Vogel, 157 Neb. 670, 61 N.W.2d 245 (1953) (best evidence reasonably available is sufficient). But see note 136 infra. See also McCormick, Damages $\$ \$ 26$, 27, 31 (1937).

124. Tuttle v. Bootes Hatcheries \& Packing Co., 112 F. Supp. 705 (D. Minn. 1953) (plaintiff's opinion on costs allowed) ; Morgan v. Young, 203 S.W.2d 837 (Tex. Civ. App. 1947) (same) ; Stott v. Johnston, 36 Cal. 2d 864, 229 P.2d 348 (1951), reversing 219 P.2d $\$ 45$ (Cal. Ct. App. 1950) (demand inferred from past sales) ; District News Co. v. Goldberg, 107 A.2d 375 (D.C. Munic. Ct. App. 1954) (same). In some cases awarding collateral profits the reports do not indicate what if any evidence was received. Gildner Bros. v. Ford Hopkins Co., 235 Iowa 191, 16 N.W.2d 229 (1944); Royal Pioneer Paper Box Mfg. Co. v. Louis De Jonge \& Co., 115 A.2d 837 ( Pa. Super. 1955).

125. Cases cited notes $128-33$ infra. Courts have, moreover, used the various verbalizations interchangeably. See, e.g., Fireside Marshmallow Co. v. Frank Quinlan Constr. Co., 213 F.2d 16 (8th Cir. 1954).

126. Lambert v. Jefferson, 251 Ala. 5, 36 So. 2d 594 (1948) (opinion and past records); Evergreen Amusement Corp. v. Milstead, 206 Md. 610, 112 A.2d 901 (1955) (opinion); Kurtz v. Oremland, 33 N.J. Super. 443, 111 A.2d 100 (Ch. 1954) (past records).

127. Biothermal Process Corp. v. Cohu \& Co., 119 N.Y.S.2d 158 (Sup. Ct.), modified, 283 App. Div. 60, 126 N.Y.S.2d I (1st Dep't 1953), aff'd mem., 308 N.Y. 689, 124 N.E.2d 323 (1954) (conflicting opinion evidence insufficient to support verdict); Willard Sales \& Serv., Inc. v. Stevens, 167 Pa. Super. 621, 76 A.2d 225 (1950) (adjustment of selling price to compensate for subcontractor's faulty work not proof of contractor's loss); E. I. du Pont de Nemours \& Co. v. Universal Moulded Products Corp., 191 Va. 525, 62 S.E.2d 233 (1950) (previously profitable business operated at a loss after breach; records insufficient to find breach caused drop to break-even point). When evidence of lost profits has been too speculative courts have, moreover, non-suited plaintiffs. Head v. Crone, 76 Idaho 196, 279 P.2d 1064 (1955) (statutory right of action); cf. Foss v. Pacific Tel. \& Tel. Co., 26 Wash. 2d 92, 173 P.2d 144 (1946) (demurrer sustained; breach not proved proximate cause of loss). See also note 52 supra. 
the profits in particular types of business, including theatrical and advertising ventures, ${ }^{128}$ as too inherently speculative to support any recovery. Some jurisdictions categorically deny recovery of lost profits when breach prevents or delays the establishment of a new, ${ }^{129}$ or the expansion of an old, ${ }^{130}$ business. Finally, courts have developed special rules which have prevented plaintiffs from even showing they were entitled to receive more than partial recovery. ${ }^{131}$

128. Evergreen Amusement Corp. v. Milstead, 206 Md. 610, 112 A.2d 901 (1955); McCormick, DaMages $\S 30$ (1935) (collecting cases). Contra Fox Midwest Theatres, Inc. v. Means, 221 F.2d 173 (8th Cir. 1955). Shealy's, Inc. v. Southern Bell Tel. \& Tel. Co., 126 F. Supp. 382 (E.D.S.C. 1954) (profits advertising might have yielded to advertiser held unrecoverable); MCCorMICK, DaArages $\$ 30$ (1935) (collecting cases).

129. E.g., Taylor v. Shoemaker, 34 Ala. App. 168, 38 So. $2 d 895$ (1948), cert. denird, 251 Ala. 601, 38 So. 2d 900 (1949); Head v. Crone, 76 Idaho 196, 279 P.2d 1064 (1955); Dieffenbach v. McIntyre, 208 Okla. 163, 254 P.2d 346 (1952).

Some courts have repudiated the idea that new business profits cannot be recovered, but nevertheless seem unfavorable toward such claims. See Evergreen Amusement Corp. v. Milstead, 206 Md. 610, 112 A.2d 901 (1955) ; Burge Ice Mach. Co. v. Strother, 273 S.W.2d 479 (Tenn. 1954); Larsen v. Knight, 233 P.2d 365 (Utah 1951). Other jurisdictions have declined to treat new businesses specially. See, e.g., Burks v. Sinclair Refining Co., 183 F.2d 239 (3d Cir. 1950) ; George W. Garig Transfer, Inc. v. Harris, 226 La. 117, 130, 75 So. $2 \mathrm{~d} 28,33$ (1954) (dictum).

130. Deering-Milliken \& Co. v. Modern-Aire, Inc., 231 F.2d 623 (9th Cir. 1955); Weiss v. Revenue Bldg. \& Loan Ass'n, 116 N.J.L. 208, 182 Atl. 891 (1936). Contra Stott v. Johnston, 36 Cal. 2d 864, 229 P.2d 348 (1951) ; Hoag v. Jenan, 86 Cal. App. 2d 556, 195 P.2d 451 (1948).

When different consequences obtain for the establishment of new, as against expansion of old, businesses, it is often unclear whether expansion in a new but related line constitutes a "new" enterprise. E.g., compare Deering-Milliken \& Co. v. Modern-Aire, Inc., supra (new product of established manufacturer is new business); Weiss v. Revenue Bldg. \& Loan Ass'n, stpra (acquiring adjacent building for expansion of rooming house is new business), with Morello v. Growers Grape Products Ass'n, $\$ 2$ Cal. App. 2d 365, 186 P.2d 463 (1947) (grower entering bottling business not new business); Hoag v. Jenan, supra (building addition to repair garage for expansion not new business); Atlantic Coast Realty Co. v. Townsend, 124 Va. 490, 98 S.E. 684 (1919) (established realtor undertaking new development project not in new business).

131. Most of the special rules are based on a theory of awarding plaintiff the value of the performance promised, less the agreed price. See cases cited note 132 infra. Evidence of loss of profit is usually excluded in determining the value of performance. See, c.g., Kurtz v. Oremland, 33 N.J. Super. 443, 11 A.2d 100 (Ch. 1954). But see Sward v. Nash, 230 Minn. 100, 105, 40 N.W.2d 828, 832 (1950) (dictum). Yet, at least when demand exceeds supply, lost profits would provide the best indication of the economic value of the contract goods. Palmer v. Connecticut Ry. \& Lighting Co., 311 U.S. 544 (1941) ; General Finance Corp. v. Dillon, 172 F.2d 924 (10th Cir. 1949) ; Matarese v. Moore-McCormack: Lines, Inc., 158 F.2d 631 ( $2 \mathrm{~d}$ Cir. 1946). The effect of the special rules therefore seems to be to reach an objective valuation without regard to any circumstances that would have made the goods more valuable to plaintiff than to the average man. See, e.g., Eastern Brass \& Copper Co. v. General Elec. Supply Corp., 101 F. Supp. 410 (S.D.N.Y. 1951). Reluctance to use loss of profits as a measure of value seems to arise from judicial apprehension that extremely high valuations will result. 1 BonBright, VAlUatron of Property 272 (1937). The valuation concept itself can, however, lead to absurdly high measures of damages. See Brown v. Spector, 70 S.W.2d 478 (Tex. Civ. App. 1934). And see 1 Bonbright, Valuatron 
For example, when a commercial lease has been broken by the lessor, plaintiff may recover the difference between the fair rental value of the leasehold and the lease price. ${ }^{132}$ But, presumably because this measure of damages is available, the lessee is often precluded from obtaining a greater recovery even where it would seem warranted. ${ }^{133}$ The opinions announcing and reiterating these standards of foreseeability and certainty seldom seem aware that there is an alternative position. ${ }^{134}$

\section{Summary}

Results in recent cases indicate that both the possibility of disproportionately large verdicts and the difficulty of proving lost profits have had an important but not necessarily consistent effect on judicial responses. ${ }^{135}$ In the buyer-manufacturer cases, where there are no inherent safeguards against

of Property 272-73, 317 (1937) (juries, and sometimes courts, often reach similarly high results without respect to the theoretical measure of damages).

132. Weiss v. Revenue Bldg. \& Loan Ass'n, 116 N.J.L. 208, 182 At1. 891 (1936).

When a lease has been broken, the lessee may recover the costs of moving, improving and leasing new premises, but not compensation for interim loss. Paul v. Camden Motor Co., 221 Ark. 702, 255 S.W.2d 418 (1953). Similarly, damages for faulty construction are, rather than profit lost during delay, cost to repair, Van Deusen Aircraft Supplies, Inc. v. Terminal Constr. Corp., 3 N.J. 321, 329, 70 A.2d 65, 68 (1949) (dictum), or the difference between value as warranted and actual value, Kendrich v. White, 75 Ga. App. 307, 43 S.E. $2 \mathrm{~d} 285$ (1947). The usual measure of damages for breach of a contract to sell realty is the value of the realty minus the agreed price; a large minority of states allow, instead, reimbursement for purchase money paid and expenses incurred. 5 ConBIN $\$ \S 1097-98$; MeCoraitck, DaAiages c. 28 (1935).

Rental value has also been used as the measure of damages for: breach of sale of assets and good will of a retail shop, Kurtz v. Oremland, 33 N.J. Super. 443, 111 A.2d 100 (Ch. 1954); failure to deliver a tractor, Page v. Hancock, 200 S.W.2d 421 (Tex. Civ. App. 1947) ; delay in completing a building, Johnson-Johnson, Inc. v. Farah, 123 Ind. App. 87, 108 N.E.2d 638 (1952) ; breach of covenant to repair leased premises, see cases collected Annots. 2 S A.L.R.2d 446, 480-92 (1953), 38 A.L.R.2d 682, 717-20 (1954). See also McCoRMick, DaMAGES 106 (1935).

133. These rules are frequently said to be the measure of general damages, and lost profits the measure of special damages. E.g., Tooke v. Allen, 85 Cal. App. 2d 230, 192 P.2d 804 (1948) (wrongful eviction); Perkins v. Langdon, 237 N.C. 159, 74 S.E.2d 634 (1953) (breach of lease) ; Sward v. Nash, 230 Minn. 100, 105, 40 N.W.2d 828, 832 (1950) (dictum) (delay in completing building). At other times, "value" and loss of profits are used interchangeably. E.g., Chain Belt Co. v. United States, 115 F. Supp. 701 (Ct. Cl. 1953) ; McCullagh v. Goodyear Tire \& Rubber Co., 342 Mich. 244, 69 N.W.2d 731 (1955) ; Gore v. Sindelar, 71 N.E.2d 414 (Ohio Ct. App. 1947). Consequently, it is often difficult to tell whether courts are departing from the special (valuation) rule or using loss of profits as evidence of value. See, e.g., Stimac v. Wissman, 342 Mich. 20, 69 N.W.2d 151 (1955); cf. 1 Bondright, Valuation of Property 290 (1937).

134. See, c.g., Evergreen Amusement Corp. v. Milstead, 205 Md. 610, 112 A.2d 901 (1955). At other times courts seem deliberately to have ignored contrary precedent. See, eg., Arkwright Mills v. Clearwater Mfg. Co., 217 S.C. 530, 61 S.E.2d 165 (1950). See also note 130 supra.

135. Only occasionally do the opinions express concern with the problems. See Flug v. Craft Mfg. Co., 3 Ill. App. 2d 56, 120 N.E.2d 666 (1954) (disproportionate loss) ; Larsen 
unexpectedly large verdicts, and proof problems are the greatest, ${ }^{136}$ the courts deny recovery of lost profits far more frequently than in direct or resale profits cases. ${ }^{137}$ Part of the disparity undoubtedly stems from the greater difficulty of proving estimated losses, ${ }^{138}$ but the courts have overcome or ignored similar problems in the direct and resale profits cases, where there are inherent limits upon the possibility of unduly large verdicts.

It is clear from the cases that the foreseeability and certainty rules, to the extent that they are still employed, fail to solve either the large verdict or the proof problems. Neither term has been defined by the courts in relation to the underlying problems involved. For example, the foreseeability test has been invoked to preclude recovery when no large verdict problem was present. ${ }^{139}$ In addition, since the test as such does not distinguish between large and small claims, the courts have held that large losses were foreseeable

v. Knight, 233 P.2d 365 (Utah 1951) (proof); Thurner Heat Treating Co. v. Memco, Inc., 252 Wis. 16, 30 N.W.2d 228 (1947) (disproportionate loss).

136. See text at notes 61-62,107-08 supra.

Courts also seem to allow recovery more readily when plaintiff is claiming a profit that defendant has realized. Neither proof nor large verdict problems are as difficult in these cases as in the usual buyer case's; plaintiff's loss can be proven from the record of, and is limited by, defendant's gain. Compare Taylor v. Kaufhold, 368 Pa. 538, 84 A.2d 347 (1951), with Macchia v. Megow, $355 \mathrm{~Pa} .565,50$ A.2d 314 (1947) (no prior resale contract); compare London v. Zachary, 92 Cal. App. 2d 654, 207 P.2d 1067 (1949), with Dieffenbach v. McIntyre, 208 Okla. 163, 254 P.2d 346 (1952) (use of past sales to infer demand); compare King v. Gerold, 109 Cal. App. 2d 316, 240 P.2d 710 (1952), with Willard Sales \& Serv., Inc. v. Stevens, $167 \mathrm{~Pa}$. Super. 621, 76 A.2d 225 (1950) (change in resale price as measure of middleman's loss). But see Sumlin v. Woodson, 211 Ark. 214, 199 S.W. 936 (1947) (lost profit denied in unlawful detainer action).

137. In more than 200 cases reported from 1946 to 1955 , plaintiff recovered in about $90 \%$ of the direct profits cases, $75 \%$ of the resale profits cases, and $50 \%$ of the buyer-manufacturer cases. In one case the court mislabeled plaintiff's loss a direct profit, had no difficulty allowing recovery by relying on precedents allowing direct profits but denying: collateral profits. Hoag v. Jenan, 86 Cal. App. 2d 556, 195 P.2d 451 (1948).

138. This seems apparent from the use of the special rules limiting recovery : the "new business" rule has been held inapplicable to sellers. Kelly v. Valley Constr. Co., 43 Wash. 2d 679, 262 P.2d 970 (1953) ; cf. Atlantic Coast Realty Co. v. Townsend, 124 Va. 490, 98 S.E. 684 (1919) (rule narrowly defined in suit by seller). See also Page v. Hancock, 200 S.W.2d 421 (Tex. Civ. App. 1947), Super-Cold Southwest Co. v. Green \& Romans, 196 S.W.2d 340 (Tex. Civ. App. 1946), where the court stated that collateral profits can be recovered only when measurable by resale contracts or prevailing market prices. But sec Morgan v. Young, 203 S.W.2d 837 (Tex. Civ. App. 1947).

139. E.g., Oxford Sporting Goods Mfg. Co. v. Gillman, 97 Ohio App. 269, 125 N.E.2d 214 (1953); Arkwright Mills v. Clearwater Mfg. Co., 217 S.C. 530, 61 S.E.2d 165 (1950); Burge Ice Mach. Co. v. Strother, 273 S.W.2d 479 (Tenn. 1954).

In addition, use of the special requirement of a prior resale contract, see note 122 supra, which seems to be drawn from the foreseeability rule, often denies recovery for claims that present no serious disproportionate damages problem. See, e.g., Clyde Coal Co. v. Pittsburg \& L.E.R.R., $226 \mathrm{~Pa}$. 391, 75 At1. 596 (1910) (profit from selling coal, compared to profit from transporting coal). The serious disproportionate damages cases arise in the telegram and public carrier cases, which are relatively few. See cases collected in Foss v. Pacific Tel. \& Tel. Co., 26 Wash. 2d 92, 173 P.2d 144 (1946) ; 5 Corbin $\$ \S 1016,1018$. 
when the nature of the contract provided constructive notice of the loss at contract time. ${ }^{140}$ In turn, the certainty rule has been used to avoid difficult proof problems, ${ }^{141}$ but it has also been used to deny claims raising less difficult problems of proof than many easily overcome by the courts in direct and resale profits cases. ${ }^{142}$ Thus there are no established standards by which the parties to commercial contracts are able to determine before litigation whether losses are too large to permit compensation, or whether the available evidence will support recovery. ${ }^{143}$

\section{The Problems Reconsidered}

Criticism of existing law does not imply that a simple solution is possible; the problems of proof and the dangers of excessive verdicts are substantial, and hard and fast rules are as difficult to propose as they are impossible to use. It is suggested, however, that many difficulties would be obviated if each problem were treated as it arose. The problem of proof should be dealt with separately, and the rule of certainty should be modified to allow some recovery although the exact amount of loss cannot be assessed. ${ }^{144}$ The large verdict problem should also be dealt with separately, and only after plaintiff has proved that he is otherwise entitled to an award of damages. The rule of foreseeability should be abandoned and replaced with more direct criteria to determine whether the damages are too large to be

140. Cases cited notes 105,120 supra.

141. See, e.g., E. I. du Pont de Nemours \& Co. v. Universal Moulded Products Corp., 191 Va. 525, 62 S.E.2d 233 (1950); cases cited note 39 supra.

142. Compare, e.g., Kurtz v. Oremland, 33 N.J. Super. 443, 111 A.2d 100 (Ch. 1954); Dieffenbach v. McIntyre, 208 Okla. 163, 254 P.2d 346 (1952); Burge Ice Mach. Co. v. Strother, 273 S.W.2d 479 (Tenn. 1954), with cases cited notes 49-57, 93-100 supra. The certainty rule, moreover, is usually applied after all plaintiff's evidence has been heard; frequently the evidence could serve as a basis for partial recovery. See, e.g., Haddad v. Western Contracting Co., 76 F. Supp. 987 (N.D. W. Va. 1948) ; Addison Miller, Inc. v. United States, 70 F. Supp. 893 (Ct. Cl.), cert. denied, 332 U.S. 836 (1947) ; Paul v. Camden Motor Co., 221 Ark. 702, 255 S.W.2d 418 (1953).

143. 1 Bonbright, Valuation of Property 289 (1937); see case's cited notes 130-34 supra. Courts' opinions have often increased the difficulty of prediction. In some cases the appellate courts have been unable to determine even from the certified record what measure of damages was applied by the trial court. E.g., Laird v. Steinmann, 97 Cal. App. 2d 781, 218 P.2d 780 (1950) ; Inland Products Corp. v. Donovan, Inc., 240 Minn. 365, 378, 62 N.W.2d 211, 221 (1953). Businessmen have deplored the unpredictability of contract damage actions. WaRd \& Harfieid, Bank Credits and Acceptances 35 (3d ed. 1948); McNaughton, A Businessman's Opinion of the Law, 6 ORE L. Rev. 108, 111 (1927) ; cf. Comment, 57 YALE L.J. 1360 n.1 (1948). The courts have recognized this uncertainty. E.g., S. Solomont \& Sons Trust, Inc. v. New England Theatre Operating Corp., 326 Mass. 99, 93 N.E.2d 241 (1950).

144. See notes 146-61 infra and accompanying text.

Some courts have recognized the desirability of partial recovery. See, e.g., Palmer v. Connecticut Ky., 311. U.S. 544 (1941) ; Schoenberg v. Forrest, 253 S.W.2d 331 (Tex. Civ. App. 1952). Cf. E. I. du Pont de Nemours \& Co. v. Universal Moulded Products Corp., 191 Va. 525, 62 S.E.2d 233 (1950). But see notes 159-61 infra and accompanying text; notes 121-30 supra and accompanying text. 
borne solely by the defendant, and, if so, how best to allocate the loss between the parties. ${ }^{145}$

\section{The Certainty Rule Reconsidered: The Rules of Evidence and the Problem of Proof}

The rule of certainty should be modified, and the standards of evidentiary admissibility aligned more closely to the realities of commercial practice. Courts should not exclude information used by businessmen in reaching business decisions, nor require appreciably more information than businessmen commonly use. Higher standards make proof of elements essential to the establishment of valid claims either expensive or impossible; many legitimate claims are not compensated because of failure to prove demand or costs with exacting detail. Other claims are overly compensated because courts do not require, and often do not admit, types of evidence that would gauge more accurately the costs plaintiff did not incur.

In the century since the certainty rule was formulated, the rules of admissibility have moved closer to commercial practice. Business records and market summaries, constantly used by businessmen to analyze their own problems, ${ }^{146}$ have gained increasing acceptance in the courts. ${ }^{147}$ Objections on hearsay grounds have been displaced by recognition of their importance in proving the effects of commercial transactions; their reliability has been accepted largely because the business world accords them importance. ${ }^{148}$ Records of past operations and past prices have simplified the proof of future demand and cost schedules. ${ }^{149}$ Further simplification can be achieved by using expert opinion based upon these records. ${ }^{150}$ Observing and classiflying the economic effects of joint cost expenditures, accountants have developed widely used

145. See notes $162-76$ infra and accompanying text.

146. See, e.g., N.Y. Times, Mar. 30, 1956, p. 25, col. 2.

147. See note 41 supra.

148. See, e.g., Massachusetts Bonding \& Ins. Co. v. Norwich Pharmacal Co., 1S F.2d 934 (2d Cir. 1927) ; Morgan, Evidence: Sone Proposals for Reford c. 5 (1927); notes $40-41$ supra.

149. Compare, e.g., Chain Belt Co. v. United States, 115 F. Supp. 701 (Ct. Cl. 1953) (use of business records to prove manufacturer's profit margin), with MoRGan, EvIDENCE: SOME Proposals fOR Reform 54-63 (1927) (difficulty of proving simple business transactions under common law rules); Ehrich, Unnecessary Difficulties of Proof, 32 Yale L.J. 436 (1923) (same). See also Comment, 35 Calif. L. REv. 434 (1947) (discussing foundation required for admission of business records).

150. The courts have begun to admit expert opinion based on reliable business reports, even though the reports are hearsay, whenever the expert's testimony is necessary to efficient adjudication. See United States v. Aluminum Co., 35 F. Supp. 820 (S.D.N.Y. 1940); Schooler v. State, 175 S.W.2d 664 (Tex. Civ. App. 1943) ; Maguire \& Hahesy, Requisite Proof of Basis for Expert Opinion, 5 VAND. L. Rev. 432 (1952).

Expert opinion has simplified proof of lost profits in many cases. See, c.g., Flagg v. Andrew Williams Stores, Inc., 127 Cal. App. 2d 165, 273 P.2d 294 (1954) (business consultant's opinion on amount of business lost to competitor); Ball v. Stokely Foods, 37 Wash. 2d 79, 221 P.2d 832 (1950) (agronomist's opinion on quality and quantity of produce). 
principles of joint cost allocation $;^{151}$ from studies of production records industrial engineers have induced principles of widespread acceptance for predicting manufacturing costs. ${ }^{152}$ As the sciences of analyzing business costs and market behavior achieve maturity, expert witnesses, particularly courtappointed experts, promise to be of great service in facilitating problems of proof. ${ }^{153}$

However, the business world now relies on many new sources of information that the courts have not yet accepted. ${ }^{\mathbf{1 5 4}}$ The field of statistical analysis offers special promise of increasing the accuracy with which lost profits can be calculated. The commercial world commonly uses predictions of future demand made by market analysts after studies of random or stratified samplings of consumer demand and preference $;^{155}$ the validity of frequency distribution has been proved both in industry and the physical sciences. ${ }^{156}$ It is still likely that the hearsay rule will be regularly invoked to preclude the admissibility of many market surveys, ${ }^{157}$ but as commercial usage becomes more widespread, judicial doubts as to the necessity and the reliability of such evidence may be expected to subside. Use of court-appointed experts will increase reliability and make judicial inquiry into the underlying data unnecessary in most cases. ${ }^{158}$

151. FTC, Costs Report 18, 21-25; Sevin, Distribution Cost Analysis 9-13, 30, 35-51 (Dep't of Commerce Economic Series No. 50, 1946) ; Sevin, How Manufacrurers Renuce Their Distribution Costs 6-12 (Dep't of Commerce Economic Series No. 72, 1948) ; Comment, 49 Nw. U.L. Rev. 237 (1954) ; cf. Paton, Advanced Accounting 166 (1947).

152. Bethel, Atwater, Saith \& Stackman, Industrial Organization and ManAGEMENT 211-26, 411-14, 425-30, 595-604 (1954) (hereinafter cited as Betren); SMITH is Duncan, Elemientary Statistics and Applications 16-8 (1944).

153. Hand, Historical and Practical Considerations Regarding Expert Testimony, 15 Harv. L. REv. 40 (1901) ; note 158 infra. The parties can also facilitate proof by agreeing to refer the question of amount of loss to an auditor, see Himmelstein v. Budner, $93 \mathrm{~F}$. Supp. 946 (D.D.C. 1950), master or appraiser.

154. See Evergreen Amusement Corp. v. Milstead, 206 Md. 610, 112 A.2d 901 (1955); note 155 infra; $c f$. Notes, 66 Harv. L. Rev. 498 (1953) (use of public opinion polls), 52 Mír. L. Kev. 914 (1954) (same).

155. See, e.g., Bethel 62-65, 68-\$6, 161 ; N.Y. Times, Dec. 11, 1955, § 3, p. 1, col. 4 (plans for $\$ 120,000,000$ aluminum plant expansion based on market survey); National Industrial Conference Board Studies in Business Policies No. 77, Forecasting in InuUstrx 41-45 (1956); Sarite \& Duncan, op. cit. supra note 152, at 8-9.

156. Bethel 390-92, 408-10; National Industrial Conference Board Studies in Eusiness Policies No. 77, Forecasting in Industry (1956); Smith \& Duncan, op. cit. supra note 152, c. 1. Substantial room for improvement still remains, however, both in the theory of frequency distribution and in the application of theory to specific situations. For discussion of the current use of statistical analysis to advance the study of economics see Ruggles, Mcthodological Developments, in 2 A SuRvey of Contemporary Economics 408, 417-37, 443-50 (1952).

157. See Irvin v. State, 66 So. 2d 288 (Fla. 1953), cert. denied, 346 U.S. 927 (1954) (public opinion poll inadmissible); Waterbury, Opinion Surveys in Civil Litigation, 44 Trude-Mark Rep. 343 (1954); Notes, 66 Harv. L. Rev. 498 (1953), 52 Mrch. L. Rev. 914 (1954).

158. Sce N.Y. Times, Jan. 24, 1956, p. 33, còl. 5 (Court-appointed medical experts reduced court congestion and reduced exaggerated claims in tort cases); Hand, supra 
Aside from its obsolesence as a standard of admissibility, the certainty rule contains a second defect: it promotes a theory of damages which supports all-or-nothing recovery rather than compromise. The rule precludes weighing relative probabilities or awarding partial recoveries. ${ }^{150}$ In this sense the certainty rule blends with the cause rule: when the amount of profits lost is indeterminate, the courts sometimes feel that the fact of loss cannot be sufficiently related to the breach to justify any recovery. ${ }^{160}$ This merger of certainty and cause, however, is not so much an aspect of the proof problem as it is an alternative rule to ward off possible large verdicts more commonly treated under the foreseeability rule. ${ }^{161}$

The Foreseability Rule Reconsidered: The Large Verdict Problem and the Possibility of Partial Recoveries

The rule of foreseeability should be abandoned; it does not and cannot provide satisfactory criteria by which to allocate the loss of disproportionate profits. Since Hadley $v$. Baxendale, ${ }^{162}$ the courts have attempted to restrict unduly large verdicts by denying compensation unless at contract time the defendant could have foreseen or had been notified that the losses were probable consequences of breach. ${ }^{163}$ The usual rationale of this rule has been that if defendant could have foreseen the risk of such liability, he might have refused to enter the contract or might have made provisions to insure against the risk. ${ }^{104}$

There are several defects in the foreseeability rule as a workable solution to the large verdict problem. First, the rule usually permits only all-or-nothing recovery. ${ }^{165}$ Secondly, claims too large to be borne by one party are often

note 153, at 56-57; Sink, The Unused Power of a Federal Judge to Call His Own Expart Witness, 29 So. Calif. L. Rev. 195, 196-205 (1956).

159. E.g., Western Union Tel. Co. v. R. J. Jones \& Sons, 211 F.2d 479 (5th Cir. 1954); Shealy's, Inc. v. Southern Bell Tel. \& Tel. Co., 126 F. Supp. 382 (E.D.S.C. 1954) ; Head v. Crone, 76 Idaho 196, 279 P.2d 1064 (1955). Contra, Smith v. Onyx Oil \& Chemical Co., 120 F. Supp. 674 (D. Del. 1954), modified, 21S F.2d 104 (3d Cir. 1955) ; Osmose Wood Preserving $\mathrm{Co}$. of Canada v. Osmose Wood Preserving Co. of America, 74 F. Supp. 435 (W.D.N.Y. 1947). All or nothing recovery also creeps into other measures of damages. See note 6 supra.

160. E.g., Western Union Tel. Co. v. R. J. Jones \& Sons, supra note 159; Head v. Crone, supra note 159; E. I. du Pont de Nemours \& Co. v. Universal Moulded Products Corp., 191 Va. 525, 62 S.E.2d 233 (1950). See Note, 17 Minn. L. REv. 194, 196 (1933); note 30 supra. Yet the problems of cause and amount can sensibly be segregated. See Note, 46 HaRv. L. Rev. 696 (1933).

161. See, e.g., Foss v. The Pacific Tel. \& Tel. Co., 26 Wash. 2d 92, 173 P.2d 144 (1946) (collecting cases); 5 Corbin $\$ 1018$; note 36 supra and accompanying text.

162. 9 Ex. 341, 156 Eng. Rep. 145 (1854).

163. See notes 23-24,31-36 supra and accompanying text; MCCONMICK, DANaGES $\$ 140$ (1935).

164. Hadley v. Baxendale, 9 Ex. 341, 156 Eng. Rep. 145 (1854); 5 CORBIN § 1008. It is also argued that the defendant might have required additional compensation. Ibid.

165. See, e.g., Flug v. Craft Mfg. Co., 3 Ill. App. 2d 56, 120 N.E.2d 666 (1954) ; Richardson v. Crone, 127 Mont. 200, 258 P.2d 970 (1953) ; Clyde Coal Co. v. Pittsburgh \& L.E.R.R, 226 Pa. 391, 75 Atl. 596 (1910). But see E. I. du Pont de Nemours \& Co. v. Universal 
foreseeable at contract time, whereas many small claims often are not. ${ }^{166}$ In addition, there is often a disparity between what a court determines was foreseeable and what in fact was foreseen. ${ }^{187}$ A more fundamental objection to the rule is its emphasis on the intent of the parties at contract time. This intent is a fiction, detracting from the real problem: allocation of loss after a contract has been breached.

As a fiction, the foreseeability rule fails to distinguish foreseen from unforeseen losses. ${ }^{108}$ In operation the rule treats losses which were foreseeable by defendant as if they were foreseen by him; it treats losses not foreseeable by defendant as if they were foreseen only by the plaintiff. But the loss of profits resulting from breach is seldom foreseen by either plaintiff or defendant at contract time. Businessmen's primary expectations are of full performance; they do not consider the possibilities of large losses that, in retrospect, might have been foreseeable for the reason that they do not normally contemplate breach. $^{100}$ Moreover, when the parties actually do foresee the risk of loss, they generally allocate that risk, either by a contractual provision for liquidated damages ${ }^{\mathbf{1 7 0}}$ or by a tacit or express agreement which can be proved by parol. ${ }^{171}$ But the foreseeability rule is not applied when the loss was in fact

Moulded Products Corp., 191 Va. 525, 62 S.E.2d 233 (1950) (part of loss foreseeable); Thurner Heat Treating Co. v. Memco, Inc., 252 Wis. 16, 30 N.W.2d 228 (1947) (no implied undertaking to compensate for full loss, but part of loss compensable). The foreseeability rule does not preclude restitutionary relief. See, e.g., Huler v. Nasser, 322 Mich. 1, 33 N.W.2d 637 (1948).

166. 1 Bonbright, Valuation of Property 291 (1937); McCorarick, Danaages $\$ 140(1935)$.

167. Ibid; cases cited notes 105,120 supra. Courts have also arbitrarily held losses foresceable when they probably were not reasonably foreseeable. See, e.g., Cohen v. Wozniak, 16 N.J. Super. 510, 85 A.2d 9 (Ch. 1951) (lessee's business becoming unprofitable).

168. 5 CoRsin $\$ 1009$; Brumby Metals, Inc. v. Spalding Foundry Co., 89 Ga. App. 464, 79 S.E.2d 568 (1953) (dictum).

169. See note 1 supra.

170. A promisor aware of but unwilling to assume the risk of profits that might be lost by his breach could insert in the contract a provision (1) liquidating or setting a maximum on the amount of damages, see 5 CoRbIN c. 58; Note, 5 Stan. L. Rev. 822 (1953); and/or (2) liquidating the type of damages by expressly assuming or disclaiming liability for named types of losses. See Consolidated Flour Mills Co. v. File Bros. Wholesale Co., 110 F.2d 926 (10th Cir. 1940) (provision limits liability to reliance interest to be established by mathematical formula); Otis Elevator Co. v. Standard Constr. Co., 92 F. Supp. 603 (D. Minn. 1950) (provision disclaims liability for consequential damages). See also Note, 99 U. PA. L. REv. 229, 237-42 (1950).

171. Since liability for loss is not a question of interpretation of contract, 5 CoRBIN $\$ 1010$, parol evidence that the parties agreed to an allocation of risk of loss is collateral to, and does not contradict, the written terms of the principal contract. Cf. Barco Mach. Products Co. v. Turner Printing Mach., Inc., 103 N.E.2d 823 (Ohio Ct. App. 1951). Evidence of the agreed allocation would not, therefore, be barred by the parol evidence rule. 3 Corbry $\$ \$$ 582-86; see Stebbins v. Selig, 257 Fed. 230, 234 (8th Cir.), cert. denied, 250 U.S. 669 (1919) (dictum). A statute of fraud problem might arise; the principal contract may, however, be taken as a written "memorandum" indicating an oral allocation of foreseen losses. 
considered; the rule is invoked only when a court must effect an allocation for which the parties failed to provide. The rule is realistic only in the rare situation in which the parties actually did foresee, but did not expressly allocate, the risk of loss of profits. As a result, the foreseeability rule penalizes one party for omissions made by both at contract time. The rule implicitly assumes that these losses, whether or not foreseen in fact, always were foreseeable by the plaintiff, and that plaintiff was under a duty to communicate to defendant the possibility of risks that were not otherwise foreseeable by him. ${ }^{172}$ From the failure of both parties to provide for damages, it is concluded that plaintiff should bear or has agreed to bear the risk of "unforseeable," and defendant the risk of "foreseeable," losses resulting from defendant's breach. ${ }^{173}$

The fiction created fails to determine with any accuracy which party should bear the risk of loss when it materializes. By focusing on the intent of the parties at contract time the foreseeability rule emphasizes events which have no significance; for even though the parties could have allocated the loss, in fact they did not. Moreover, by looking to contract time, the foreseeability rule ignores the status of the parties at the time when a mutually unforeseen loss has actually occurred. It thereby immunizes one party from the loss even though that party can best bear or morally ought to bear all or part of the loss.

Finally, the result is inconsistent with the basic tenet of contract damages: a defendant is ordinarily liable in damages not because he undertook to be liable, but because he breached a contract, and the community interest requires him to compensate plaintiff for resultant losses in order to protect the plaintiff's expectation and reliance interests. ${ }^{174}$ It is true that in the lost profits area this rule must be modified ${ }^{175}$ the community interest in compensation is often frustrated by difficulties of proof or outweighed by questions of disproportionate damages. But when lost profits recovery should be modified, the analysis should be made directly in terms of the competing interests warranting protection, and not through an unexpressed and fictional intent of the parties.

The allocation of loss should be made by the courts as a matter of law in order to promote results in accord with the competing interests involved. Courts should consciously and directly attempt to strike a compromise between

172. "No doubt the plaintiff nearly always knows his own business and circumstances better than the defendant; he knows the other facts that will accompany the defendant's breach, enabling him to foresee the injury if he thinks of the matter at all. ... Therefore, when courts say that both must have had reason to foresee the injury, the meaning is that the defendant must have had reason to foresee it." 5 CoRBIN $\$ 1010$.

173. Globe Refining Co. v. Landa Cotton Oil Co., 190 U.S. 540 (1903) ; Snell v. Cottingham, 72 Ill. 161 (1874) ; 5 CoRBIN $\$ \$ 1009-10$. The doctrine of the Landa case, that damages should be denied unless defendant expressly or impliedly undertook the risk of loss, has been repudiated by courts and commentators. See authorities collected in 5 CoRBrN $\$ 1010$; McCoruick, Danages $\$ 141$ (1935); Restatearent, Contracts $\$ 330$, comment $a$ (1932).

174. See notes 18-22 supra and accompanying text.

175. See notes 24-27 supra and accompanying text. 
the desirability of protecting plaintiff's expectation interest, compensating him fully for losses caused by the breach, and the undesirability of imposing such severe liability that not only breach but also future formation of commercially useful contracts are deterred. The courts must also consider the reasonableness of the parties' conduct before, at, and after breach, and their relative ability to distribute the immediate loss and the risk of similar future losses to those who benefit from the type of commercial transaction immediately involved. ${ }^{170}$ Theoretically, the allocation may be made by placing the risk entirely on defendant, entirely on plaintiff or partially on both. When the profits lost are quite large, however, an all-or-nothing allocation, placing the entire loss on one party, seldom gives sufficient weight to all the interests involved.

\section{Syuthesis of the Problems: A Suggested Procedure}

When lost profits resulting from breach prove to be disproportionate to the benefit defendant would have received, partial recovery should be given to plaintiff after balancing the interests involved. The courts should initially

176. Plaintiff receives compensatory damages largely because the community's interests are thereby served, and defendant is relieved from the burden of making full indemnity because disproportionate damages would adversely affect the interests of other contractors and the community. Although moral "fault" should not be in issue, the allocation should not ignore commercial conduct which weakens a party's claims for judicial protection. Although caused by breach, the loss may be disproportionate largely because one of the parties did not follow ordinary commercial practices by which he could have made loss of profits an avoidable consequence of breach. Cf. notes 4-17 supra and accompanying text. Thus, it may have been commercially unwise for plaintiff not to have made a duplicate supply contract before breach, or not to have allowed for short delays, in order to insure that a large undertaking would not be frustrated; it may have been equally unwise for defendant not to have taken steps that would have assured plaintiff of prompt delivery without adding substantially greater cost or inconvenience to defendant's preparations. See Western Union Tel. Co. v. R. J. Jones \& Sons, 211 F.2d 479 (5th Cir. 1954) ; Gee v. The Lancashire \& Xorkshire Ry., 6 H. \& N. *211, 158 Eng. Rep. 87 (Ex. 1860). Such lack of commercial wisdom may not be sufficient to require defendant to bear all or none of the loss, but the comparative unvisdom of their preparation would seem relevant to the comparative allocation of the loss.

In addition, a defendant engaged in an industry that normally stands a high risk of disproportionate loss may be able to shift his loss to others who benefit from that industry; allocating to him the loss caused by his breach would have less effect on the ability and willingness of businessmen to undertake future risks, and may seem less unfair, than burdening those sellers of customized, high cost, low volume goods or services who must absorb the loss themselves. Risk-shifting, on the other hand, may be undesirable in many cases. Regulated industries-telegram companies, carriers, for example-can not refuse to serve a customer who has large collateral undertakings dependent upon the utility's low cost service; nor, in many cases, can the regulated utility take special steps to insure that the marginal customer's collateral plans will not be frustrated. Although their high volume and low costs make regulated services better risk distributors than most businesses, liability for large damages may be undesirable when it shifts to commercially prudent customers the loss of a customer who could, at low cost, have made a duplicate supply contract or allowance for delay to obviate the possibility of disproportionate loss from the utility's breach. 
determine whether the loss was both caused by the breach and within plaintiff's expectation interests. Cause should mean "cause in fact," and the expectation interest should be what plaintiff could reasonably have foreseen. ${ }^{177}$ If these questions are answered affirmatively, the courts should then ascertain the amount of loss that probably resulted from the breach. When the total amount lost is not certain, damages should be awarded for that part of the loss which has been shown; profits and costs that cannot be measured with complete accuracy should be approximated as closely as possible rather than overlooked. When it is not certain whether plaintiff's business venture would have produced any profit, courts should award plaintiff damages corresponding to the "value of the chance" to make profits which was lost because of the breach. ${ }^{178}$ Admittedly, these amounts will at times be speculative, but awarding the closest approximation possible is preferable to awarding nothing because the loss could not be precisely calibrated. Only when this approximation has been made should the courts inquire whether plaintiff would be given a recovery disproportionately greater than the benefit defendant could have gained by performance. If the answer to this inquiry is affirmative, the courts should reduce the verdict to an amount reasonably related to the policy of deterring contract breaches and of enforcing businessmen's expectation interests.

The suggested procedure is not a panacea; it neither eliminates nor resolves all problems, but it brings relevant considerations to the fore, and avoids couching them behind semantic distinctions which preclude analysis. The weight to be given competing factors is often a matter of subjective determination; the courts will seldom be able to fix an amount of damages which will bring the conflicting interests into exact balance. But by isolating the proof and excessive verdict problems when they are present, courts will be able to deal with them directly. By considering the underlying problems directly, and abandoning a fictional or all-or-nothing approach, the courts can obtain more accurate and more realistic results. Finally, by using the suggested analysis the courts will enable the parties to the litigation to determine what factors influence their decisions, and therefore to develop a more sensible theory of the case.

177. If plaintiff could not foresee the profit from defendant's performance the profit is, of course, not within plaintiff's expectation. If plaintiff could reasonably foresee the profit it seems immaterial whether he actually contemplated the relationship between his collatcral plans and defendant's promise. See Fuller \& Perdue, The Reliance Interest in Contract Damages, 46 YALE L.J. 52, 54 (1936) ; cf. 5 CORBIN $\$ \$ 1009-11$.

Although losses caused-in-fact by breach are limited to those foreseeable by plaintiff, this rule of causation should not be identified with the foreseeability rule, which refers solely to defendant's ability to foresee. See note 172 supra. Combining the two aspects of foresctability, by defining cause to include defendant's ability to foresee, seems an unnecessary source of confusion. See note 30 supra.

178. See Matthews v. Continental Roll \& Steel Foundry Co., 121 F.2d 594 (3d Cir. 1941); Notes, 28 Colvar. L. Rev. 76 (1928), 46 HARv. L. REv. 696 (1933); note 96 supra and accompanying text. 


\section{ConCLUSION}

Claims for contract damages measured by plaintiff's loss of profits present two troublesome problems that seldom arise when plaintiff's loss can be fully compensated by the market formula. Proof of the profit lost often requires cumbersome, detailed evidence; once proved, the loss may be so great that it cannot practicably be absorbed by either party.

To treat these problems, the courts have developed rules of foreseeability and certainty. Today these rules are applied differently in three distinct categories of cases. Modern courts nearly always award full compensation to sellers, and in order to do so, have severely narrowed the rules. However, in this area, the rules are not needed at all, since proof problems are seldom serious and large verdict problems cannot arise.

Judicial treatment of suits by middlemen against breaching suppliers is changing. The courts seem to be extending to the buyer-middleman the same liberality accorded sellers. The result seems well justified even though the foreseeability and certainty rules are being confined in the process; the problems present in resale cases are seldom great. Proof problems inherent in breach of franchise cases contain, however, a potential source of difficulty. If these problems materialize, the courts may distinguish between franchise cases and other buyer-dealer suits, continuing their liberality toward the latter but subjecting franchise cases to exacting standards.

Suits by buyer-manufacturers have been particularly troublesome. In this area, where problems of proof and possibilities of large losses are most real, the inadequacy of the foreseeability and certainty rationales is most apparent. Courts are constantly presented with the paradox of applying semantic tests, formulated in the last century, to situations arising in today's commercial world. At times, courts accommodate the rules to the apparent interests of the parties. Generally, however, the courts rigorously apply older definitions of foreseeability and certainly, often denying claims that presented no actual proof or disproportionate loss problem.

If the past course of lost profits cases is the guide to the future, the failures of the foreseeability and certainty rules will multiply. Apart from the changes in the rules of evidence, as business practices become known and standardized and as knowledge of the nature and effects of economic forces increases, the old definitions of foreseeability and certainty diverge increasingly from business realities. This widening disparity critically weakens the effectiveness of the rules. In addition, parties cannot predict when courts will depart from the older standards of certainty and foreseeability. Thus promisees and their creditors cannot predict whether, should breach occur, their expectation and reliance interests or investments will be recouped.

There are more direct methods of meeting problems of proof. The courts can admit the best evidence of loss available and fix the amount of loss by weighing probabilities. Often the best, and least complex, evidence of loss will be opinions of experts or hearsay ordinarily relied upon by businessmen. When 
this evidence indicates that plaintiff has probably sustained any part of the loss alleged, partial recovery should be awarded.

When breach of commercial contracts causes disproportionately large loss, judicial allocation of the loss should be directly related to the basic purposes of compensatory damages. The courts should consciously weigh the beneficial effects of promoting commercial reliance and protecting credit values against the possible harmful effects of causing investors and businessmen to think of defendant's trade as one carrying unacceptably high risks.

Although the process of balancing interests can seldom lead to an exact solution, it allows a more accurate allocation than the present rules permit. The analysis proposed considers, rather than ignores, the factors most relevant to the problem; it invites information and argument directed toward the real problems rather than toward obsolescent definitions. And each of these advantages is calculated to assure businessmen that a commercial contract is an adequate basis for credit and for reliance.

\section{Offers of Proof: A Theory of the Case}

Many claims for lost profits fail because of inadequate preparation for trial. Some businessmen have been unable to recover damages because their accounting systems and cost records did not accurately reflect their past operations. ${ }^{170}$ More often, however, injured parties have lost because their claims went to trial without a theory of the case that covered the question of damages. ${ }^{150}$ Buttressing the relevance of an offer of proof with a logical theory of the case will often facilitate the admission of the evidence offered and help to sustain the verdicts obtained.181

179. E. I. du Pont de Nemours \& Co. v. Universal Moulded Products Corp., 191 Va. 525, 62 S.E.2d 233 (1950) ; United States Naval Academy Alumni Ass'n v. American Publishing Co., 195 Md. 150, 72 A.2d 735 (1950).

180. See, e.g., Maxwell v. Schaefer, 381 Pa. 13, 112 A.2d 69 (1955) ; Page v. Hancock, 200 S.W.2d 421 (Tex. Civ. App. 1947) ; Iverson v. Schnack, 263 Wis. 266, 57 N.W.2d 400 (1953). One reason for incomplete offers of proof may be incomplete understanding of accounting principles. See Sayre, Book Review, 25 Iowa L. REv. 193, 194 (1939).

Another common reason for no recovery is failure to allege inability to make a substitute contract in the market, see, e.g., Oxford Sporting Goods Mfg. Co. v. Gillman, 97 Ohio App. 269, 125 N.E.2d 214 (1953), or failure to allege lost profits as special damages, see, e.g., Price v. Goodman, 226 N.C. 223, 37 S.E.2d 592 (1946) ; Super-Cold Southwest Co. v. Green \& Romans, 196 S.W.2d 340 (Tex. Civ. App. 1946). See also H. J. McGrath Co. v. Wisner, $189 \mathrm{Md} .260,55 \mathrm{~A} .2 \mathrm{~d} 793$ (1947) (defendant's lost profit cannot be recovered by general plea to action in assumpsit). Recent cases, however, have awarded lost profits as general damages when plaintiff's expectation of profit was obvious from the nature of the contract. Murarka v. Bachrack Bros., Inc., 215 F.2d 547 (2d Cir. 1954); Victoria Laundry, Ltd. v. Newman Industries, Ltd., [1949] 2 K.B. 528 (C.A.)

181. See, e.g., Tucson Federal Sav. \& Loan Ass'n v. Aetna Inv. Corp., 74 Ariz. 163, 245 P.2d 423 (1952). A logical theory of the case, developed at the trial, is important on appeal. Nearly all cases cited herein are decisions on appeal by defendant. Plaintiff often obtains satisfactory results at the trial, but loses all or part of his verdict when defendant appeals. 
The theory of the damages should be directed first toward establishing that plaintiff suffered some loss, then toward measuring the amount of loss. The first step is more important; when the fact of some loss has been proved, most courts will tend to award damages to prevent the breaching party from profiting from uncertainty created by his own wrongdoing. ${ }^{182}$ However, when given no logical estimate of the losses claimed, courts may find that the fact of loss has become too "contingent" for judicial recognition. ${ }^{183}$ Evidence of the amount of loss should be directed toward a logical computation of both income and costs; in many unsuccessful cases one or both sides of the profits equation was not covered by the evidence..$^{184}$ Courts have occassionally denied recovery because a relatively minor contingency was not covered by the evidence. ${ }^{185}$ Usually, however, they have found that the evidence omitted an important cost item or furnished no reasonable basis for inferring probable demand. ${ }^{186}$

Proof of income can be of three types. Courts have permitted recovery based on future income inferred solely from past sales. ${ }^{187}$ The inference may sometimes be strengthened by market reports showing change or lack of change in prices and consumption during the period covered by the past records and the period following the breach. ${ }^{188}$ Damages have also been measured by inferring the demand for plaintiff's product from the sales of

Appellate courts will probably be inclined to sustain the trial court's judgment when the record discloses its logical, as well as evidentiary, basis.

182. See cases cited note 66 supra.

183. See, c.g., Fireside Marshmallow Co. v. Frank Quinlan Constr. Co., 213 F.2d 16 (Sth Cir. 1954); Addison Miller, Inc. v. United States, 70 F. Supp. 893 (Ct. Cl.), cert. denicd, 332 U.S. 836 (1947) ; Evergreen Amusement Corp. v. Milstead, 206 Md. 610, 112 A.2d 901 (1955). See note 160 supra and accompanying text (merger of "cause" and "certainty" rules).

184. E.g., Burks v. Sinclair Refining Co., 183 F.2d 239 (3d Cir. 1950) (no proof of costs); Warren Post No. 23 Am. Legion v. Jones, $302 \mathrm{Ky} .861,196$ S.W.2d 726 (1946) (both) ; California Eastern Airways, Inc. v. Alaska Airlines, Inc., 38 Wash. 2d 378, 229 P.2d 540 (1951) (income).

185. See, e.g., Western Union Tel. Co. v. R. J. Jones \& Sons, 211 F.2d 479 (5th Cir. 1954) (government did not have to accept lowest construction bid); Busam Motor Sales, Inc. v. Ford Motor Co., 85 F. Supp. 790, 796 (S.D. Ohio 1949) (dealer might decline to profit by filling orders) ; Bristol Belt Line Ry. v. Bullock Elec. Co., 101 Va. 652, 44 S.E. 892 (1903) (during temporary suspension of railway, operator may save more than fuel and skilled labor costs).

186. E.g., Sumlin v. Waodson, 211 Ark. 214, 199 S.W.2d 936 (1947) (demand); McPherson v. Dukes, 314 Ky. 70, 234 S.W.2d 307 (1950) (costs); Iverson v. Schnack, 263 Wis. 266, 57 N.W.2d 400 (1953) (costs).

187. Stentor Elec. Mffg. Co. v. Klaxon Co., 115 F.2d 268 (3d Cir. 1940), rev'd other grounds, 313 U.S. 487 (1941) ; Tucson Federal Sav. \& Loan Ass'n v. Aetna Inv. Corp., 74 Ariz. 163, 245 P.2d 423 (1952); Kay Petroleum Corp. v. Piergrossi, 137 Conn. 620, 79 A.2d $\$ 29$ (1951).

1SS. See Osborne \& Epstein, Corporate Profits since World War II, Survey of Current Business, Jan. 1956, p. 8, 12-15 (profit margins generally follow business levels). Other methods of showing change in demand have been used. See Stott v. Johnston, 36 Cal. 2d \$64, 229 P.2d 348 (1951) (judicial notice); Joest v. John A. Denie's Sons Co., 174 Tenn. 
similar enterprises. ${ }^{189}$ The comparative demand for the competing products may be shown by past records or by those factors which strongly affect consumer preferences. ${ }^{190} \mathrm{~A}$ third method of proving income is to make an entirely theoretical computation of future demand. The information originally used by plaintiff in making his plans should be examined for possible use as evidence; trade journals, government publications and, perhaps, consumer surveys may also be admissible to show demand. ${ }^{191}$

Cost can be proved both by past records ${ }^{192}$ and expert opinion evidence. ${ }^{103}$ Courts favor the former method, ${ }^{194}$ but have admitted accountants' opinions ${ }^{105}$ and may admit industrial engineers' opinions on joint selling and manufacturing costs. ${ }^{196}$ When plaintiff's cost records are voluminous, it is usually desirable to have an expert accountant prepare a summary or abstract to offer into evidence, and to afford defendant a reasonable opportunity before trial

410,126 S.W.2d 312 (1939) (same). At times the problem has been ignored. See Quist v. Zerr, 12 Wash. 2d 21, 120 P.2d 539 (1941) (gasoline sales at outbreak of war).

189. Flagg v. Andrew Williams Stores, Inc., 127 Cal. App, 2d 165, 273 P.2d 294 (1954) ; Perkins v. Langdon, 237 N.C. 159, 74 S.E.2d 634 (1953); accord, Freedom Oil Works Co. v. Williams, 302 Pa. 51, 152 Atl. 741 (1930). Contra, Evergreen Amusement Corp. v. Milstead, $206 \mathrm{Md}$. 610, 112 A.2d 901 (1955). See also cases cited note 188 supra. 190. Flagg v. Andrew Williams Stores, Inc., supra note 189; Pace Corp. v. Jackson, 275 S.W.2d 849 (Tex. Civ. App. 1955). Some reasonable basis for comparison is essential. Sumlin v. Woodson, 211 Ark. 214, 199 S.W.2d 936 (1947); Kurtz v. Oremland, 33 N.J. Super. 443, 111 A.2d 100 (Ch. 1954).

191. See George W. Garig Transfer, Inc. v. Harris, 226 La. 117, 75 So. $2 d 28$ (1954) (evidence of market surveys plaintiff made prior to contract in order to assess value of franchise admitted to show value after defendant breached contract to deliver franchise); note 148 supra.

192. Houston Ready-Cut House Co. v. United States, 96 F. Supp. 629 (Ct. Cl. 1951); Tucson Federal Sav. \& Loan Ass'n v. Aetna Inv. Corp., 74 Ariz. 163, 245 P.2d 423 (1952); Eastern Ky. Lumber \& Development Co. v. Waddell, 239 S.W.2d 68 (Ky. 1951).

193. Hinckley v. Pittsburgh Bessemer Steel Co., 121 U.S. 264 (1887); Stolteben v. General Foods Corp., 79 F. Supp. 228 (S.D.N.Y. 1948) ; Kelly v. Valley Constr. Co., 43 Wash. 2d 679, 262 P.2d 970 (1953). A competitor's costs may also be used to prove what plaintiff's costs would have been to do the same job. Western Union Tel. Co. v. R. J. Jones \& Sons, 211 F.2d 479 (5th Cir. 1954). See also cases collected WRIGHT, RENIEDIES 362-65 (1955).

194. See, e.g., Burge Ice Mach. Co. v. Weiss, 219 F.2d 573 (6th Cir. 1955) ; Black v. Love \& Amos Coal Co., 30 Tenn. App. 377, 206 S.W.2d 432 (1947); National School Studios, Inc. v. Superior School Photo Service, 40 Wash. 2d 263, 242 P.2d 756 (1952).

195. Betterman v. American Stores Co., 367 Pa. 193, 80 A.2d 66 (1951) ; Smith v. Onyx Oil \& Chemical Co., 120 F. Supp. 674 (D. Del. 1954), modified, 218 F.2d 104 (3d Cir. 1955). See also Flagg v. Andrew Williams Stores, Inc., 127 Cal. App. 2d 165, 273 P.2d 294 (1954) (business consultant); 26 CAN. B. REv. 873 (1948),

196. See Kelly v. Valley Constr. Co., 43 Wash. 2d 679, 262 P.2d 970 (1953) (engineers) ; cf. Roberts Distributing Co. v. Kaye-Halbert Corp., 272 P.2d 886 (Cal. Dist. Ct. App. 1954) (plant manager); Sawyer, Accounting and Statistical Proof in Price Discrimination Cases, 36 Iowa L. REv. 244, 252-54 (1951). For discussion of the current methods for predicting future profits by combining the expert knowledge of accountants and industrial engineers see Dean, Methods and Potentialities of Break-Even Analysis, in StudIes in CosTrNg 227 (1952). 
to check the expert's accuracy. ${ }^{197}$ Costs have frequently been proven solely by the testimony of the owner or manager of a small enterprise. ${ }^{198}$

Evidence of the profit a new business would have made should be developed . to meet two specific problems. Recent cases suggest that the profits of a new business are too speculative because there is no evidence either that they have been well planned or that they will be expertly managed. ${ }^{199}$ When the claim for lost profits is brought to trial after the new business has been started, its records may be relevant to these questions. ${ }^{200}$ In other cases direct evidence of management's experience and planning in other ventures should be offered to meet this objection. ${ }^{201}$ Since breach usually causes delay in starting a new business, courts have also been concerned with the speculative character of the evidence offered to show that the business would have been profitable during the period of the delay. ${ }^{202}$ Plaintiff's actual loss in these cases, however, is one of time: the business must still pass through the initial risky period. If the business actually starts and becomes profitable, plaintiff will be earning profits

197. Compare Emich Motors Corp. v. General Motors Corp., 181 F.2d 70 (7th Cir. 1950); Jacobs v. A. Solomon, 219 La. 237, 52 So. $2 d 763$ (1951), with Augustine v. Bowles, 149 F.2d 93 (9th Cir. 1945); Royal Pioneer Paper Box Mffg. Co. v. Louis de Jonge \& Co., 115 A.2d 837 (Pa. Super. 1955). An accountant's testimony of past costs will generally be inadmissible, or if admitted insufficient to support a verdict, unless the records on which the accountant's testimony is based are available in court. Cabel v. United States, 113 F.2d 998 (1st Cir. 1940) ; Alexander's Dep't Stores, Inc. v. Ohrbach's, Inc., 269 App. Div. 321,56 N.Y.S.2d 173 (1st Dep't 1945).

198. E.g., Garrett v. Faust, 9 F.R.D. 482 (E.D. Pa. 1949), rev'd other grounds, 183 F.2d 625 (3d Cir. 1950), cert. denied, 340 U.S. 931 (1951); Angus v. Roth, 98 Cal. App. 2d 672, 220 P.2d 429 (1950); Geluska v. Scharoum, 87 N.Y.S.2d 381 (Sup. Ct. 1949).

199. The courts denying new business profits seldom state their objections, but. stveral cases allowing profits to new undertakings have emphasized the presence of evidence indicating that the enterprise would have succeeded. Standard Mach. Co. v. Duncan Shaw Corp., 208 F.2d 61 (1st Cir. 1953) (joint venturers' experience in producing, selling product) ; Chain Belt Co. v. United States, 115 F. Supp. 701 (Ct. Cl. 1953) (previous expierience of management; machine tools and skilled labor assembled); Harrell v. Davis, 210 Ark. 939, 198 S.W.2d 180 (1946) (assembling equipment and crew assembled, working one day). See also E. I. du Pont de Nemours \& Co. v. Universal Moulded Products Corp., 191 Va. 525, 62 S.E.2d 233 (1950) (change of plant manager decreased probative value of past records in proving costs) ; Strietelmeier v. Angelo, 113 N.E.2d 771, aff'd, 113 N.E.2d 777 (Ohio C.P. 1951) (financial debility in past is evidence that no profit was lost after breach).

200. See Harrell v. Davis, supra note 199.

201. In Gruber v. S-M News Co., 126 F. Supp. 442 (S.D.N.Y. 1954), evidence of this type was considered, but held insufficient to prove the demand the new enterprise would have enjoyed.

202. Many new businesses start with (1) sharply limited capital or weak management, Karlan, Surall Business: Its Place and Problenss 65-68 (1948); Senate T.N.E.C., Mongograph 17, Problems of Small Business \&S (1941), (2) non-recurring starting expenses, and (3) the necessity of creating demand. There is therefore a high risk of loss during the initial period. Evergreen Amusement Corp. v. Milstead, 206 Md. 610, 112 A2d 901 (1955); Crum, Age Structure of the Corporate System c. 5 (1953); Kaplan, op. cit. supra at $66-67$. 
that he would have earned earlier but for the breach. The amount of his loss may be approximated as interest for as long a period as he is likely to earn a profit, based on the amount of profit he earns during a period equal to that of the delay. ${ }^{203}$

203. The loss of a new business delayed by breach can best be illustrated by a graph showing the profit experience of the business during its life and plotting the rate of earning profit (e.g., dollars per day) at the time it starts and at subsequent times. In the graph below the lower curve $P_{1}$ represents the actual profit experience of a hypothetical new business, commencing at its actual starting date and extending indefinitely. Assuming that breach caused the business to have the same experience it otherwise would have had, but at a later time, then the curve $P_{2}$-an identically shaped curve displaced to the left (earlier in time) by an amount $D$, equal to the delay caused by breach-represents the profit experience the business would have had absent breach. The assumption is valid in most cases. See CRUN, op. cit. supra note 202.

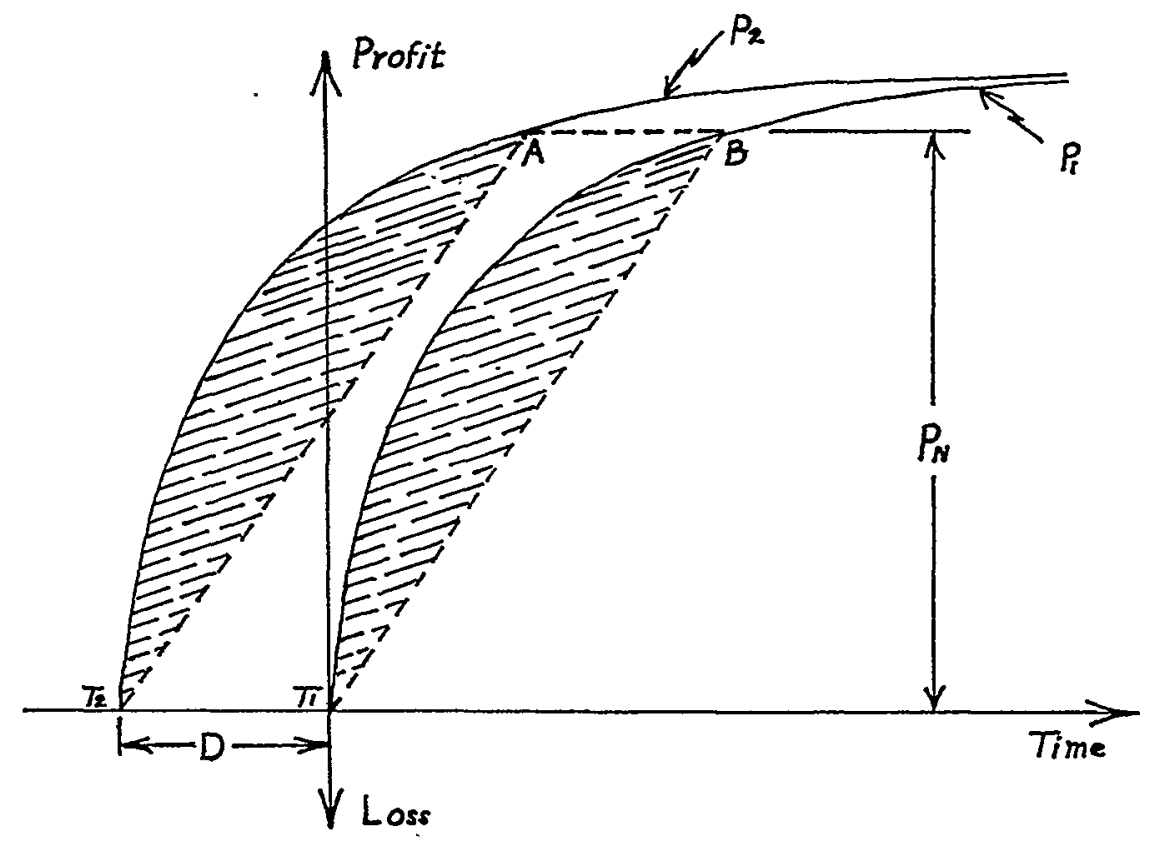

The loss caused by breach is the area between the two curves. If at the time of trial it is possible to determine the normal earning power of the business after it has become well established, the area between the two curves can easily be approximated. Line $A B$ is drawn at the determined level of normal profits, parallel to the base line $T_{1} T_{2}$. Since both curves are identically shaped, the shaded areas are identical at any profit level; consequently the parallelogram $T_{2} A B T_{1}$ equals the loss area. Since the area of a parallelogram equals its base times its height, the loss area equals the normal profit rate $P n$, times the period of delay, $D$.

One adjustment is often required, however. The above graph is drawn on the assumption that the business would continue to be indefinitely profitable. The assumption would introduce no error in measuring the loss of a business that continues until ended by war, obsolescence or some other fortuitous event; breach shortens the life of the business before 
the fortuitous event by the amount $D$. But most businesses end because of some internal or cyclical factor which may give the business a finite life whose length is independent of the starting date. KAPLAN op. cit. sippra note 202 at c. 4 . The average new business life expectancy is about six years. See N.Y. Times, Jan. 10, 1956, p. 39, col. 2; Crun. op. cit. supra at 14S. Thus the average business would end at the time 6 years if delayed by breach, and at time $6-D$ years if not delayed. Curve $P_{1}$ will therefore extend $\mathrm{D}$ further than curve $P_{2}$, and the business thus recoups its loss at the end of its life. Its damages then should be interest on the amount $P n D$ until that amount is recouped, or, actuarially, perhaps for six years. 